\title{
Article \\ Synthesis of Novel Spiro-Tetrahydroquinoline Derivatives and Evaluation of Their Pharmacological Effects on Wound Healing
}

\author{
Yan-Cheng Liou ${ }^{1,+}$, Yan-An Lin ${ }^{2,+}{ }^{+}$Ke Wang ${ }^{2}$, Juan-Cheng Yang ${ }^{3}$, Yeong-Jiunn Jang ${ }^{3, * \mathbb{C}}$, Wenwei Lin ${ }^{1}$ \\ and Yang-Chang $\mathrm{Wu}^{2,3,4, *}$ \\ 1 Department of Chemistry, National Taiwan Normal University, Taipei 116, Taiwan; \\ s89218456@gmail.com (Y.-C.L.); wenweilin@ntnu.edc.tw (W.L.) \\ 2 Graduate Institute of Integrated Medicine, China Medical University, Taichung 404, Taiwan; \\ riinryxc@gmail.com (Y.-A.L.); waker603@163.com (K.W.) \\ 3 Chinese Medicine Research and Development Center, China Medical University Hospital, \\ Taichung 404, Taiwan; qq9113054@gmail.com \\ 4 Department of Medical Laboratory Science and Biotechnology, College of Medical and Health Science, \\ Asia University, Taichung 41354, Taiwan \\ * Correspondence: jinrain.tw@gmail.com (Y.-J.J.), yachwu@gmail.com (Y.-C.W.); \\ Tel.: +886-4-22053366 (ext. 3605) (Y.-C.W.) \\ + These authors contributed equally to this work.
}

check for updates

Citation: Liou, Y.-C.; Lin, Y.-A.; Wang, K.; Yang, J.-C.; Jang, Y.-J.; Lin, W.; Wu, Y.-C. Synthesis of Novel Spiro-Tetrahydroquinoline

Derivatives and Evaluation of Their Pharmacological Effects on Wound Healing. Int. J. Mol. Sci. 2021, 22, 6251. https://doi.org/10.3390/

ijms22126251

Academic Editor: István Szatmári

Received: 6 May 2021

Accepted: 7 June 2021

Published: 10 June 2021

Publisher's Note: MDPI stays neutral with regard to jurisdictional claims in published maps and institutional affiliations.

Copyright: (c) 2021 by the authors. Licensee MDPI, Basel, Switzerland. This article is an open access article distributed under the terms and conditions of the Creative Commons Attribution (CC BY) license (https:// creativecommons.org/licenses/by/ $4.0 /)$.

\begin{abstract}
A highly diastereoselective method for the synthesis of novel spiro-tetrahydroquinoline derivatives is reported here, using a one-pot reaction method. All compounds were characterized by ${ }^{1} \mathrm{H}$-nuclear magnetic resonance (NMR) and mass spectroscopy, and their stereo configurations were confirmed by $\mathrm{X}$-ray analysis. These activities of these derivatives were then tested in human keratocyte cells. The responses of cells to treatment with selected compounds were studied using scratch analysis, and the compounds were tested in a mouse excision wound model. Three of the derivatives demonstrated significant wound-healing activities.
\end{abstract}

Keywords: tetrahydroquinoline; 1,3-indandione; spiro-tetrahydroquinoline; one-pot reaction; wound healing

\section{Introduction}

Skin is the largest organ and the first defense to protect the human body [1,2]. It can be damaged by trauma, burns, skin diseases and so on. Severe skin trauma can impose physical, psychological, and economic burdens on patients. The wound healing process involves the coordination of many distinct but overlapping physiological spaces, comprising hemostasis, inflammation, epithelial cell proliferation, and tissue remodeling [3-5]. In elderly or diabetic patients, the risk of wound infection increased due to vascular aging and the lower tissue repair capability, which may eventually lead to chronic wounds [6]. Therefore, wound healing is one of the hot topics in skin surgery. At present, few drugs have been found with substantial abilities of promoting wound healing [7]. Actually, the quality of wound regeneration mainly depends on the efficiency of wound care [8]. In this study, we synthesized a series of novel spiro-tetrahydroquinoline derivatives and compared their effects in wound healing in human epidermal cells and animal models.

Quinoline derivatives have attracted both synthetic and biological chemists because of their diverse chemical and pharmacological properties, such as anticancer, antimycobacterial, anticonvulsant, anti-inflammatory and anti-cardiovascular diseases [9]. Some quinoline derivatives were found to have wound healing activity [10-13]. Tetrahydroquinoline derivatives, which are the reduced form of quinolines, were used as antibacterials, antitumor and anti-HIV agents [14]. However, there are very few reports about tetrahydroquinoline on wound healing even though their structures are so similar to each other [15]. It 
is a curious question of whether tetrahydroquinoline will deliver similar effects on wound healing or not.

The natural pharmacophore, spiro-1,3-indandione, has attracted considerable attention due to its diverse biological activities [16-18]. Fredericamycin A was isolated from a fermentation broth of the strain Streptomyces griseus and reported to demonstrate antibiotic properties [19]. Synthetic studies were also performed to obtain additional 1,3-indandione derivatives, which demonstrated antitumor and antibiotic activities [20,21]. In recent research, the spiro-1,3-indandione moiety has been considered to represent a valuable functional group for medicinal chemistry [22]. However, the synthesis of carbon spiro1,3-indandiones remains a challenge [23,24]. Yan et al. previously synthesized spiro1,3-indandiones from cyclic azomethine imine and 2-arylideneindene-1,3-dione via 1,3dipolar cycloaddition [25]. Enders et al. used 1,4-dithiane-2,5-diol and 2-arylideneindene1,3-dione as the starting materials to obtain spiro-1,3-indandione, using a squaramidecatalyzed sulfa-Michael/aldol domino reaction [26]. As a starting material that is commonly used for the generation of spiro-1,3-indandiones, 2-arylidene-1,3-indandiones were the focus of our recent study. In our previous research, 2-arylidene-1,3-indandiones were used to obtain enantioselective spiro-nitrocyclopropanes, which contained the spiro-1,3indandione skeleton, catalyzed by cinchona alkoloid derivatives [27]. Indanedione-fused 2,6-disubstituted spiro-cyclohexanones have also been studied [28].

Recently, our team has focused on the wound-healing activities of natural products [29]. As tetrahydroquinoline and 1,3-indandione are both widely studied as pharmacophores in medicinal chemistry, we considered whether the synthesis of hybrids of tetrahydroquinoline and spiro-indandione residues could result in any meaningful active compounds. Song and Du have synthesized highly functionalized spirothiazolidinone tetrahydroquinolines via a squaramide-catalyzed cascade reaction [30]. Therefore, we synthesized spiro-tetrahydroquinolines compounds with a similar method for further study, focusing particularly on their wound-healing capabilities.

\section{Results}

The ortho- $N$-sulfonated aminophenyl $\alpha, \beta$-unsaturated ketone 1a and 2-benzylidene-1,3indandione 2a were used as model substrates for the synthesis of spiro-tetrahydroqunioline derivative 3a via an aza-Michael/Michael reaction (Table 1). Initially, the reaction of $\mathbf{1 a}$ with 2a in the presence of DABCO furnished the desired product $3 \mathbf{a}$ in $71 \%$ yield at $30{ }^{\circ} \mathrm{C}$ in $p$-xylene (Table 1, entry 1). Examination of different tertiary amines such as DMAP, $\mathrm{Et}_{3} \mathrm{~N}$ and DIPEA as catalysts did not improve the yield of the product $3 \mathbf{a}$ (Table 1, entries 2-4). It is worthy to note that all the catalysts furnished the product $3 a$ in excellent diastereomeric ratio (>20:1). Furthermore, various solvents like toluene, $\mathrm{CH}_{2} \mathrm{Cl}_{2}, \mathrm{THF}$, EtOAc and $\mathrm{Et}_{2} \mathrm{O}$ were screened to optimize the reaction conditions (Table 1, entries 5-10). The results proved that aprotic solvents are the best for the reaction conditions such as toluene and $\mathrm{CH}_{2} \mathrm{Cl}_{2}$ (Table 1, entries 5 and 6). Considering the solubility of the starting materials 1 and 2, we chose to test the $\mathrm{CH}_{2} \mathrm{Cl}_{2}$ as optimized solvent for further screening of reaction. When the reaction was carried out at $0{ }^{\circ} \mathrm{C}$, the yield of the desired product 3 a was improved to $97 \%$, but the reaction required longer times $\left(38 \mathrm{~h}\right.$ ) compared to $30^{\circ} \mathrm{C}$ (Table 1, entries 6 and 11). The reaction conditions were further evaluated by the catalyst loading and concentration of the solvent, which indicated that $5 \mathrm{~mol} \%$ of DABCO was sufficient for the completion of the reaction in $\mathrm{CH}_{2} \mathrm{Cl}_{2}(1 \mathrm{~mL})$ (Table 1, entries 12 and 13). The reaction conditions in Table 1, entry 13 were selected as the optimal conditions for further studies. The products were purified by the recrystallization, and identified by ${ }^{1} \mathrm{H}-\mathrm{NMR},{ }^{13} \mathrm{C}-\mathrm{NMR}$ and HRMS. The stereo configuration of the compound $3 \mathbf{a}$ was determined by single crystal $\mathrm{X}$-ray diffraction analysis as shown in Figure 1 [31]. 
Table 1. Optimization of conditions of the aza-Michael/Michael reaction ${ }^{\mathrm{a}}$.<smiles>O=C(/C=C/c1ccccc1NS(=O)(=O)c1ccccc1)c1ccccc1</smiles>

1a<smiles>O=C1C(=Cc2ccccc2)C(=O)c2ccccc21</smiles>

2a

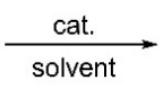<smiles>O=C(CC1c2ccccc2N(S(=O)(=O)c2ccccc2)C1c1ccccc1)c1ccccc1</smiles>

3a

\begin{tabular}{|c|c|c|c|c|c|}
\hline Entry & Cat. & Solvent & Temp. $\left({ }^{\circ} \mathrm{C}\right)$ & Time (h) & Yield $(\%)^{b, c}$ \\
\hline 1 & DABCO & $p$-Xylene & 30 & 12 & 71 \\
\hline 2 & DMAP & $p$-Xylene & 30 & 12 & 47 \\
\hline 3 & $\mathrm{NEt}_{3}$ & $p$-Xylene & 30 & 24 & 57 \\
\hline 4 & DIPEA & $p$-Xylene & 30 & 24 & 17 \\
\hline 5 & DABCO & Toluene & 30 & 12 & 91 \\
\hline 6 & DABCO & $\mathrm{CH}_{2} \mathrm{Cl}_{2}$ & 30 & 12 & 96 \\
\hline 7 & DABCO & THF & 30 & 12 & 77 \\
\hline 8 & DABCO & EtOAc & 30 & 12 & 88 \\
\hline 9 & DABCO & $\mathrm{MeCN}$ & 30 & 12 & 87 \\
\hline 10 & DABCO & $\mathrm{Et}_{2} \mathrm{O}$ & 30 & 12 & 11 \\
\hline 11 & DABCO & $\mathrm{CH}_{2} \mathrm{Cl}_{2}$ & 0 & 38 & 97 \\
\hline $12^{d, e}$ & DABCO & $\mathrm{CH}_{2} \mathrm{Cl}_{2}$ & 30 & 12 & 90 \\
\hline $13^{d, f}$ & DABCO & $\mathrm{CH}_{2} \mathrm{Cl}_{2}$ & 30 & 12 & 92 \\
\hline
\end{tabular}

${ }^{a}$ Unless noted, all reactions were carried out with $1 \mathbf{a}(0.1 \mathrm{mmol}), \mathbf{2 a}(0.1 \mathrm{mmol})$, and catalyst $(20 \mathrm{~mol} \%)$ in $0.5 \mathrm{~mL}$ solvent. ${ }^{\mathrm{b}}$ Yield and diastereomeric ratio were determined by $400 \mathrm{MHz}$ NMR with $\mathrm{Ph}_{3} \mathrm{CH}$ as an internal standard. ${ }^{\mathrm{c}}$ Diastereomeric ratio was $>20: 1 .{ }^{\mathrm{d}} 1.0 \mathrm{~mL}$ solvent was used. ${ }^{\mathrm{e}} 10 \mathrm{~mol} \%$ of catalyst was used. ${ }^{\mathrm{f}} 5 \mathrm{~mol} \%$ of catalyst was used.

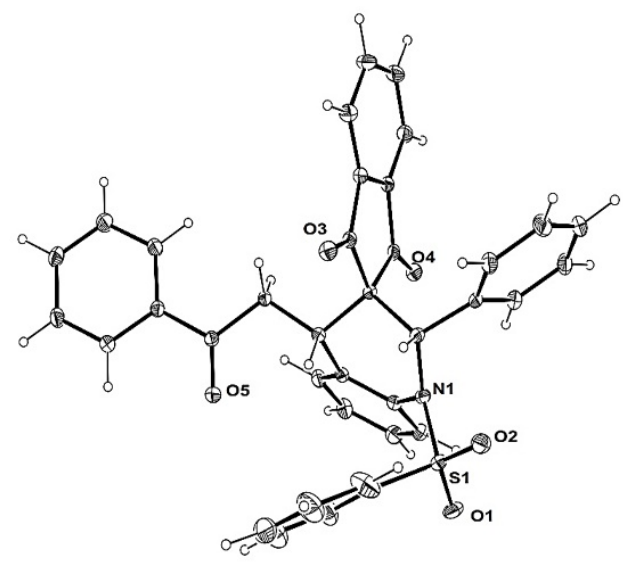

Figure 1. The single crystal X-ray diffraction of 3a.

With the optimal condition in hand, the substrate scope was further investigated. In general, all the substrates $\mathbf{1}$ and $\mathbf{2}$ with different electron-withdrawing and electrondonating $\mathrm{R}^{1}$ and $\mathrm{R}^{2}$ substituents were provided the desired spiro-tetrahydroquinolines in good to excellent yields (Table 2). At first, different indandione derivatives of $\mathrm{R}^{2}$ substituents were tested with 1a. We noticed significant steric and electronic effects of the $\mathrm{R}^{2}$ substituent in the reaction outcome. Substrates with meta- and para-bromo groups as $\mathrm{R}^{2}$ substituents reacted well with $\mathbf{1 a}$ to afford the spiro-tetrahydroquinoline products $3 \mathrm{c}$ and $\mathbf{3 d}$ in up to $83 \%$ yields within $3 \mathrm{~h}$, whereas the substrate with $\mathrm{R}^{2}$ as ortho-bromo substituent was less reactive and the desired product $3 \mathbf{b}$ was obtained in $71 \%$ yield in longer reaction times $(12 \mathrm{~h})$. It clearly indicates that the rate of the reaction is reduced by the sterically hindered substituents. We also found that the reaction rate also depends on the electronic properties of the $\mathrm{R}^{2}$ substituents. For example, the substrates bearing electronwithdrawing groups $\mathbf{2} \mathbf{d}-\mathbf{2} \mathbf{g}$ subjected with $\mathbf{1 a}$, furnished the corresponding products $\mathbf{3 d} \mathbf{- 3} \mathbf{g}$ in high yields (81-85\%) within $3 \mathrm{~h}$ (Table 1, entries $4-7$ ), but the substrate bearing an electron-donating group such as $4-\mathrm{OMePh}$ as $\mathrm{R}^{2}$ substituent $\mathbf{2 h}$ resulted in the desired 
product $3 \mathrm{~h}$ in only moderate yield (68\%), when prolonging the reaction time up to $29 \mathrm{~h}$ (Table 1, entry 8). In contrast, when substrates with heteroaryl (furyl or thienyl) groups $2 \mathbf{i}$ and $2 \mathbf{j}$ were employed, the reaction could not proceed to provide the products even after $24 \mathrm{~h}$ (Table 1, entries 9 and 10).

Table 2. Effect of different substituents on reaction rate ${ }^{\text {a }}$.

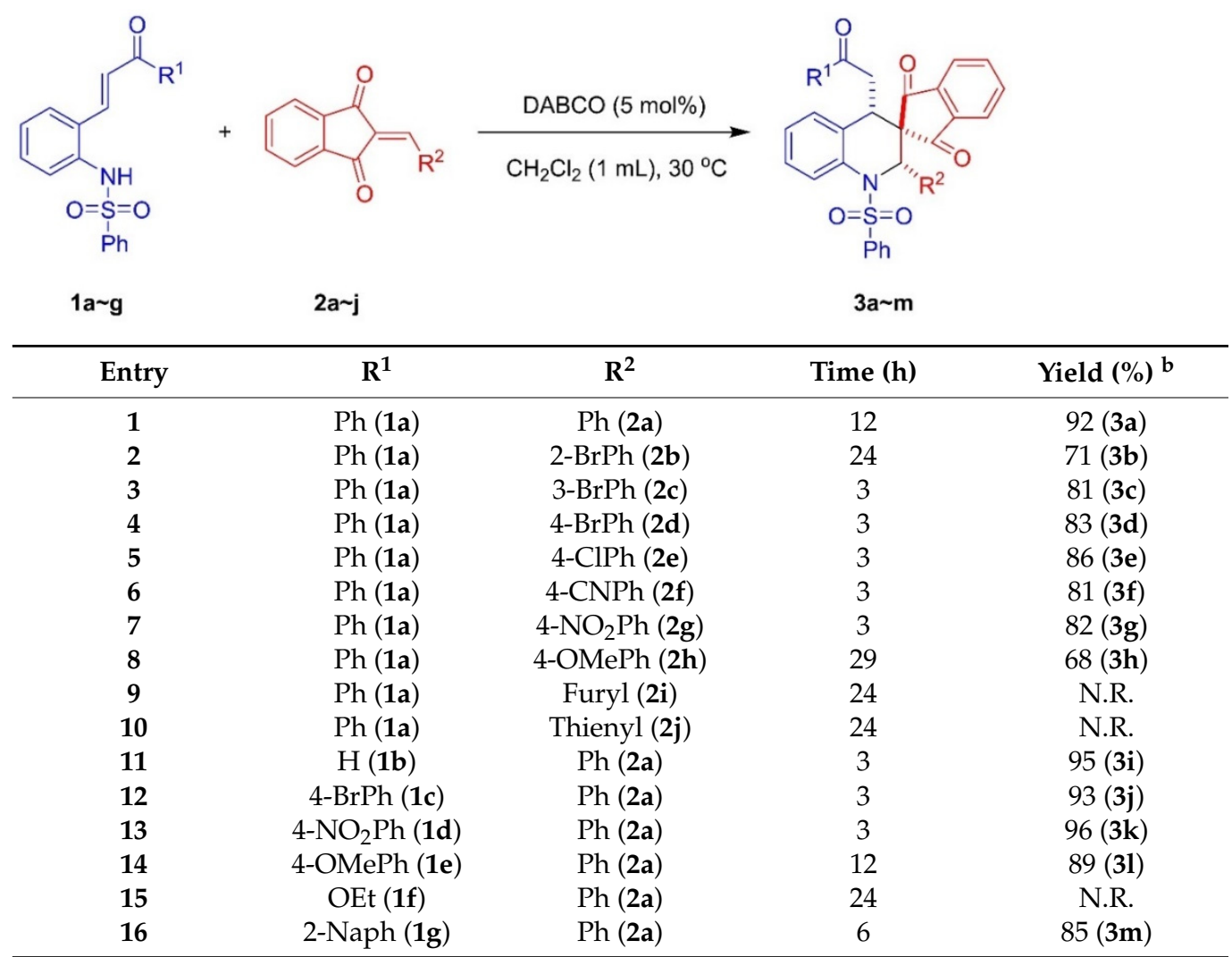

${ }^{a}$ Unless noted, all reactions were carried out with $1(0.2 \mathrm{mmol}), 2(0.2 \mathrm{mmol})$ and $\mathrm{CH}_{2} \mathrm{Cl}_{2}$ $(1 \mathrm{~mL})$ was used. ${ }^{\mathrm{b}}$ Yield of the product 3 was recrystallized from the ethanol and hexane, $\mathrm{dr}>20: 1(3 \mathbf{a}-3 \mathrm{~m})$.

Furthermore, different $\mathrm{R}^{1}$ substituents of $\mathbf{1}$ were also tested in the reaction conditions to prepare the desired spiro-tetrahydroquinolines 3 . Delightfully, the substrate having aldehyde $\left(\mathrm{R}^{1}=\mathrm{H}\right)$ group reacted well with $2 \mathrm{a}$ to afford the corresponding product $3 \mathbf{i}$ in $95 \%$ yield within $3 \mathrm{~h}$ (Table 1 , entry 11 ). As similar as $\mathrm{R}^{2}$, substrates bearing electronwithdrawing $R^{1}$ groups (1c and $\mathbf{1 d}$ ) more efficiently furnished the desired products $\mathbf{3} \mathbf{j}$ and $3 \mathbf{k}$ compared to the electron-donating group such as $\mathbf{1 e}$ (Table 1, entries 12-14). When substrate with ester group $\mathbf{1} \mathbf{f}$ was employed as the reactant, the corresponding product could not be found in the reaction (Table 1, entry 15). It could be understood that the second Michael addition was not efficient when the electron-rich ester is present rather than an aldehyde or ketone. In addition, 2-naphthyl group of $1 \mathrm{~g}$ also furnished the product $3 \mathrm{~m}$ in $85 \%$ yield in $6 \mathrm{~h}$ (Table 1 , entry 16 ).

The results of the MTT test revealed the cell viability of human keratinocyte cells (HaCaT) treated with the 13 derived compounds as shown in Table 3. The survival rates of cells treated with $\mathbf{3 b}$ were approximately $80 \%$ at all treatment concentrations (Supplementary Figure S1A). Cells treated with $3 \mathrm{c}$ displayed a survival rate of $80 \%$ at concentrations of 6.25 and $12.5 \mu \mathrm{M}$, but the growth was inhibited at concentrations equal to or greater than $25 \mu \mathrm{M}$ (Supplementary Figure S1B). Cells treated with $3 \mathbf{i}$ displayed low survival rates at concentrations greater than $25 \mu \mathrm{M}$ (Supplementary Figure S1C). Cells treated with 31 displayed a survival rate of approximately $80 \%$ at all concentrations (Supplementary Figure S1D). The survival rates of cells treated with $3 \mathrm{~m}$ at concentrations of 6.25 and $12.5 \mu \mathrm{M}$ were $80 \%$ and $60 \%$, respectively. Compared with the other tested 
compounds, the five compounds described above had little effect on HaCaT cell growth (Supplementary Figure S1), whereas the remaining compounds displayed the strong inhibition of HaCaT cell growth. The results of the remaining samples can be found in the supplementary materials. Therefore, we selected the five compounds with limited effects on cell viability for use in subsequent experiments.

Table 3. In vitro cytotoxicity data of sample.

\begin{tabular}{cccccc}
\hline \multicolumn{7}{c}{ Cell Viability after 24 Hours (\% Cell Viability) } \\
a & \\
\hline Compounds & $\mathbf{6 . 2 5}$ & $\mathbf{1 2 . 5}$ & $\mathbf{2 5}$ & $\mathbf{5 0}$ & $\mathbf{1 0 0}$ \\
\hline 3a & $51.85 \pm 1.52$ & $46.53 \pm 1.73$ & $45.02 \pm 2.07$ & $39.66 \pm 0.94$ & $36.15 \pm 0.91$ \\
3b & $91.58 \pm 3.00$ & $89.56 \pm 4.50$ & $86.63 \pm 3.02$ & $80.75 \pm 2.61$ & $75.33 \pm 2.27$ \\
3c & $92.63 \pm 1.89$ & $75.38 \pm 3.36$ & $66.05 \pm 0.57$ & $54.61 \pm 2.84$ & $44.72 \pm 4.14$ \\
3d & $71.53 \pm 3.02$ & $55.22 \pm 4.37$ & $45.98 \pm 0.63$ & $41.35 \pm 2.36$ & $35.24 \pm 0.86$ \\
3e & $59.63 \pm 3.10$ & $51.38 \pm 3.10$ & $47.06 \pm 1.18$ & $42.13 \pm 1.18$ & $37.55 \pm 1.78$ \\
3f & $43.08 \pm 2.68$ & $38.78 \pm 3.54$ & $39.22 \pm 3.23$ & $35.45 \pm 2.68$ & $27.08 \pm 6.40$ \\
3g & $49.53 \pm 0.63$ & $43.68 \pm 1.41$ & $40.21 \pm 1.04$ & $38.91 \pm 0.60$ & $33.18 \pm 1.32$ \\
3h & $73.02 \pm 3.04$ & $65.79 \pm 0.77$ & $62.66 \pm 0.96$ & $52.92 \pm 0.76$ & $43.04 \pm 1.19$ \\
3i & $87.90 \pm 5.68$ & $61.38 \pm 6.78$ & $18.21 \pm 4.26$ & $14.23 \pm 1.10$ & $14.10 \pm 1.69$ \\
3j & $40.36 \pm 1.71$ & $26.33 \pm 0.92$ & $19.02 \pm 0.40$ & $15.73 \pm 0.47$ & $11.45 \pm 0.11$ \\
3k & $20.09 \pm 0.64$ & $7.05 \pm 0.17$ & $7.15 \pm 0.07$ & $7.03 \pm 0.15$ & $7.09 \pm 0.13$ \\
31 & $87.31 \pm 0.95$ & $84.57 \pm 1.78$ & $82.97 \pm 1.22$ & $77.60 \pm 1.43$ & $76.15 \pm 2.13$ \\
3m & $84.42 \pm 1.69$ & $70.56 \pm 1.24$ & $59.69 \pm 2.02$ & $47.18 \pm 1.34$ & $35.47 \pm 0.28$ \\
\hline
\end{tabular}

a Inhibition of cell growth by the listed compounds was determined using the MTT assay. $\mathrm{HaCaT}$ are human keratinocyte cell line.

Based on the results of the cell viability experiments, the activities of the five selected compounds were evaluated in the scratch assay. The results shown in Figure 2 indicated that the wounds healed gradually healed within $15-18 \mathrm{~h}$ when the tested drugs were added to the culture medium. $\mathbf{3 b}$ had a significant effect on wound healing at the concentration of $25 \mu \mathrm{M}$, but no significant effect was observed when the concentration was increased to $50 \mu \mathrm{M}$ (Figure 3A). 3c had an effect on wound healing at concentrations of 12.5 and $25 \mu \mathrm{M}$ (Figure 3B). 3i had a significant effect on wound healing at concentrations of 12.5 and $25 \mu \mathrm{M}$. Compared with the control groups, no significant effects on wound healing were observed for low concentration $(6.25 \mu \mathrm{M})$ or high concentration $(50 \mu \mathrm{M})$ treatment with either $3 \mathbf{c}$ or $3 \mathbf{i}$ (Figure 3C). $3 \mathbf{l}$ and $\mathbf{3 m}$ displayed no significant effects on the promotion of wound healing at any of the tested concentrations and were found to have inhibitory effects (Figure 3D,E). The optimal concentration data based on these results is shown in Figure $3 F$, and the compounds $\mathbf{3 b}, \mathbf{3} \mathbf{c}$, and $\mathbf{3} \mathbf{i}$ were selected for further study in an animal model of wound closure.

Based on the results obtained from the scratch assay, wound-healing tests in mice were performed to examine the effects of wound treatment using $\mathbf{3 b}, \mathbf{3} \mathbf{c}$, and $\mathbf{3} \mathbf{i}$ (Figure $4 \mathrm{~A}$ ). The control group was observed to shed the scab on the 9th day, and the wound repair was completed on the 13th day. In mice treated with $3 \mathbf{b}$ at a concentration of $50 \mu \mathrm{M}$, the scab fell off on the 12th day, and the wound repair was completed on the 13th day (Figure 4B). Treatment with $6.25 \mu \mathrm{M}$ of $3 \mathrm{c}$ resulted in the shedding of the pupae on the 9 th day, but the wound was not completely repaired by the 13th day (Figure 4C). When a $25 \mu \mathrm{M}$ concentration of $3 \mathbf{i}$ was applied, the pupae were shed on the 11th day, and the wound was repaired. The wound healing was completed by the 11th day, and the pupae were shed on the 7th day when the concentration of $3 \mathbf{i}$ was increased to $50 \mu \mathrm{M}$ (Figure 4D). We compared the optimal concentrations of $\mathbf{3} \mathbf{b}, \mathbf{3} \mathbf{c}$, and $\mathbf{3} \mathbf{i}$ treatment based on the results of the mouse wound healing model. $3 \mathbf{i}$ was demonstrated to have the best effect on wound healing at a concentration of $50 \mu \mathrm{M}$ (Figure 4E). 


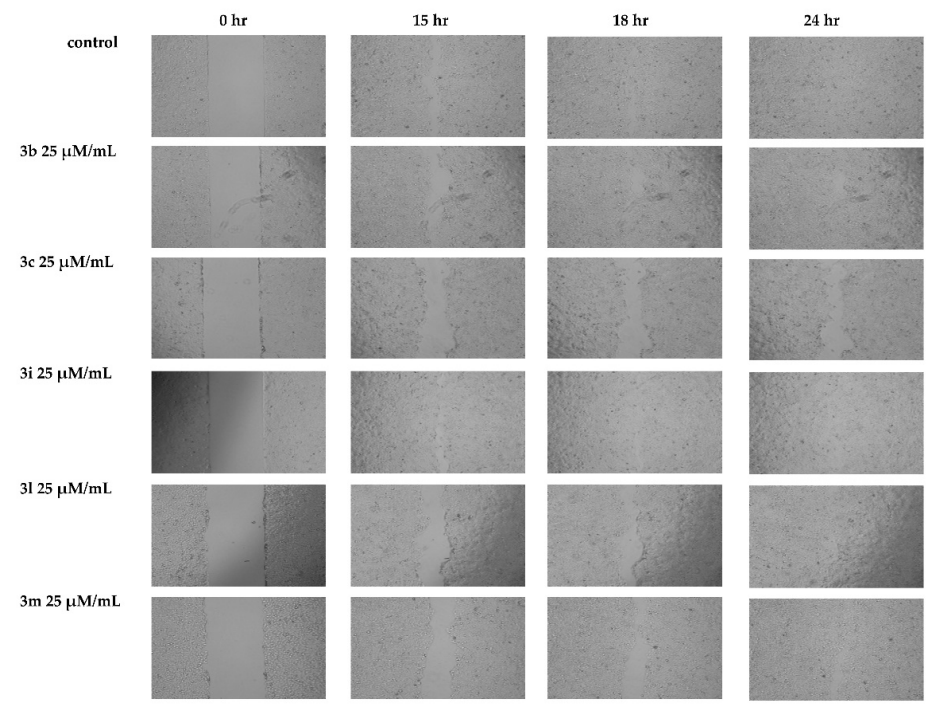

Figure 2. Representative images showing wound closures in HaCaT cells 0, 15, 18, and $24 \mathrm{~h}$ after wounding. Compounds $3 \mathbf{b}, 3 \mathbf{c}, 3 \mathbf{i}, 3 \mathbf{l}$, and $3 \mathrm{~m}$ were added to the medium to test their effects on wound healing (magnification: $4 \times$ objective). The groups with the strongest effects on cell migration are displayed in this figure. The remaining groups are shown in the supplementary materials.

(A)

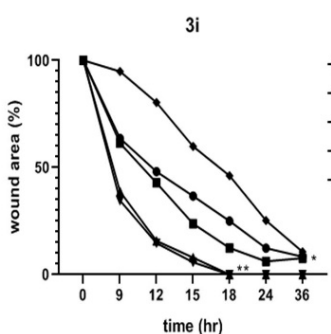

(C)

$3 b$

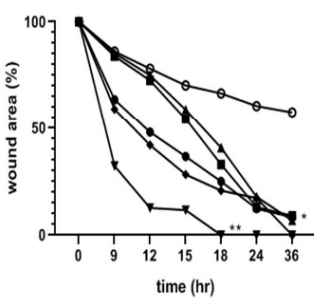

(E)

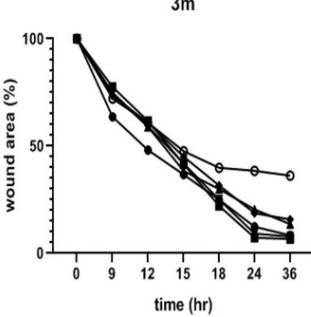

(B)
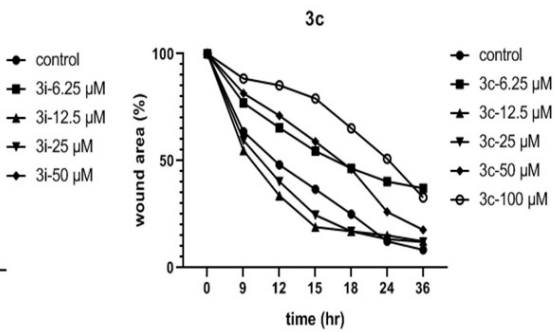

(D)

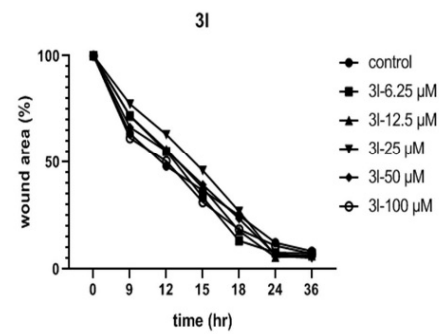

(F)

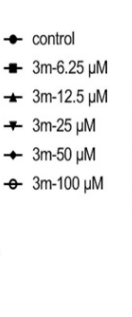

optimal concentration

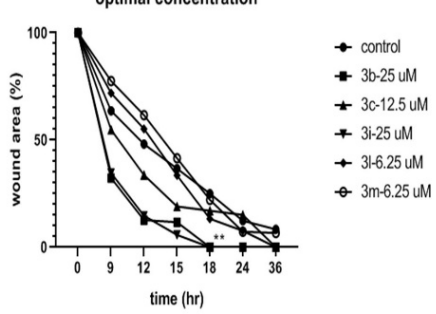

Figure 3. The migration of $\mathrm{HaCaT}$ cells treated with various doses of the derived compounds. Cells were treated with (A) 3b, (B) 3c, (C) 3i, (D) 3l, and (E) 3m at different concentrations for $24 \mathrm{~h}$ and subjected to the scratch assay. (F) Comparisons of the five compounds at their respective best concentrations after 24-h treatment in $\mathrm{HaCaT}$ cells subjected to scratch assay, expressed as a percentage of control (set as $100 \%) .{ }^{*} p<0.01,{ }^{* *} p<0.001$. 
(A)

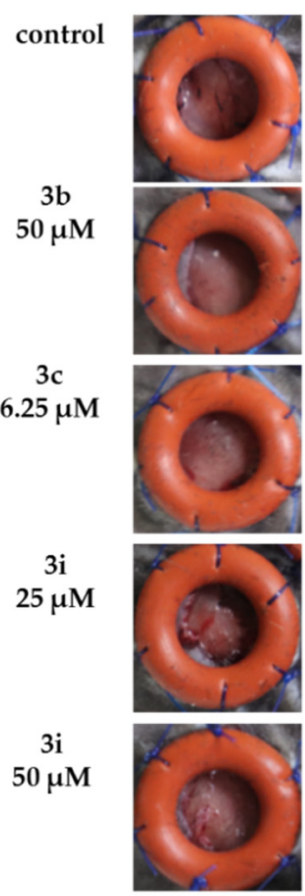

(B)

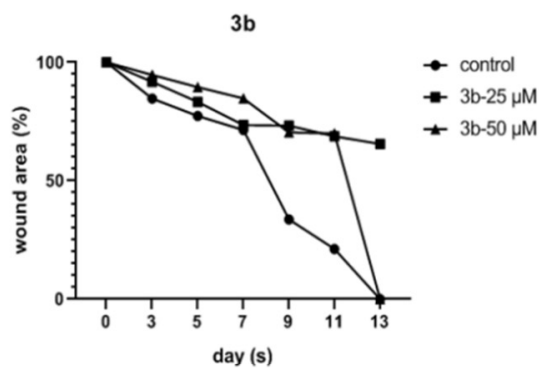

(D)

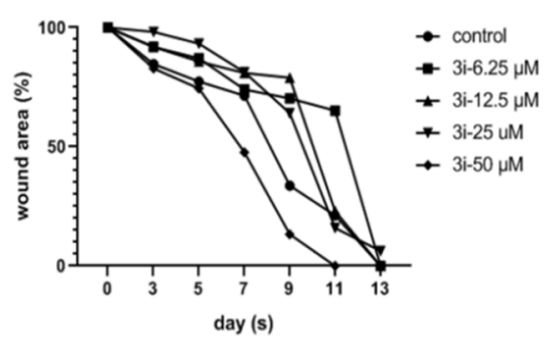

3
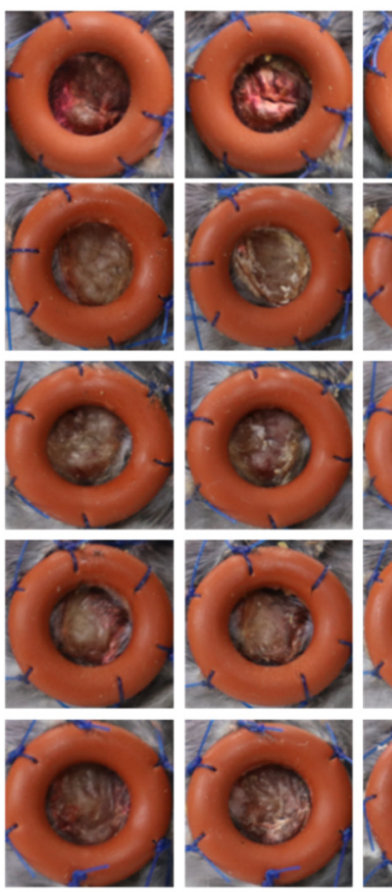

9
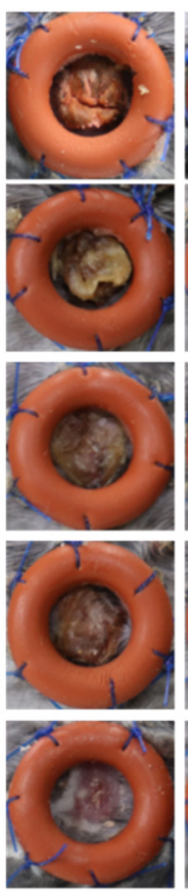

(C)
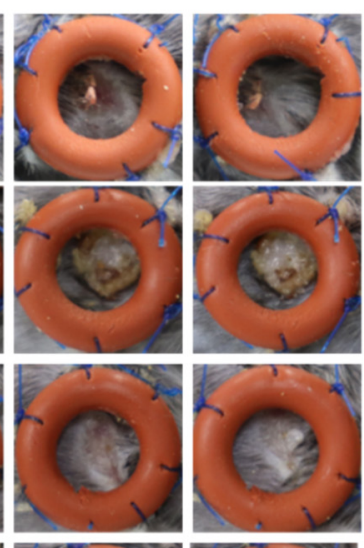

13 Day (s)
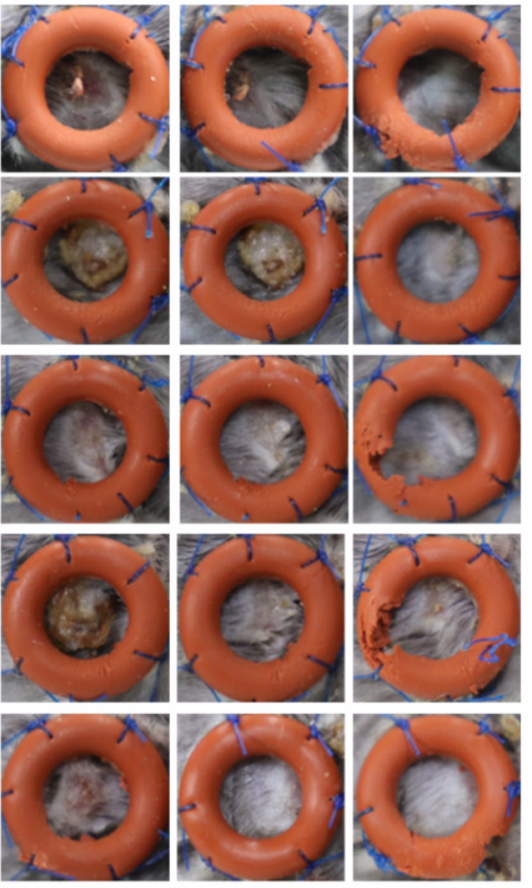

$3 c$

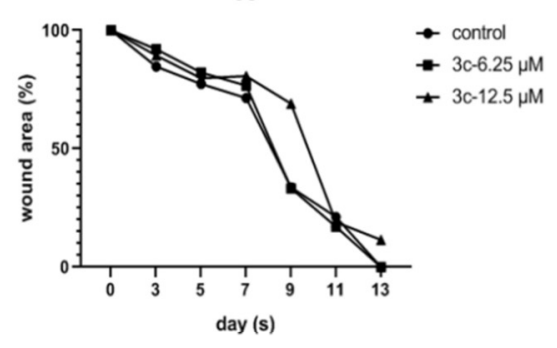

(E)

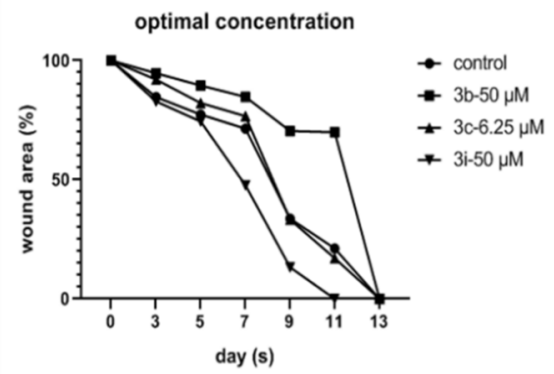

Figure 4. (A) The closure of mouse wounds treated with empty fibrin gel (control) or fibrin gel containing $3 \mathbf{b}, 3 \mathbf{c}$, and 3i. Representative pictures of the wounds are shown at days $0,3,5,7,9,11$, and 13 . Wound closure progression during treatment with (B) $\mathbf{3 b},(\mathbf{C}) \mathbf{3}$, and (D) $\mathbf{3 i}$. (E) Comparison of the effects of the optimal concentrations of $\mathbf{3 b}, \mathbf{3} \mathbf{c}$, and $\mathbf{3 i}$ on wound healing. $\mathbf{3 b}, \mathbf{3} \mathbf{c}$, and $\mathbf{3} \mathbf{i}$ are arranged in accordance with the specific concentration of each compound that was used in a gel applied to wounds in mice once per day for a total of 13 days.

\section{Discussion}

The plausible mechanism of the reaction is depicted in Scheme 1. Initially, the chalcone derivative $\mathbf{1}$ is deprotonated by tertiary amine, yielding a nitrogen-nucleophile $\mathbf{I}$ which would attack 2-arylidene-1,3-indandiones 2 to generate aza-Michael adduct II, through a first Michael addition (Scheme 1). The second intramolecular Michael addition upon 
II to provide III with both $\mathrm{R}^{1}$ and $\mathrm{R}^{2}$ in the same side and subsequent protonation and enolization would result in the spiro-tetrahydroquinolines 3 in high yields.

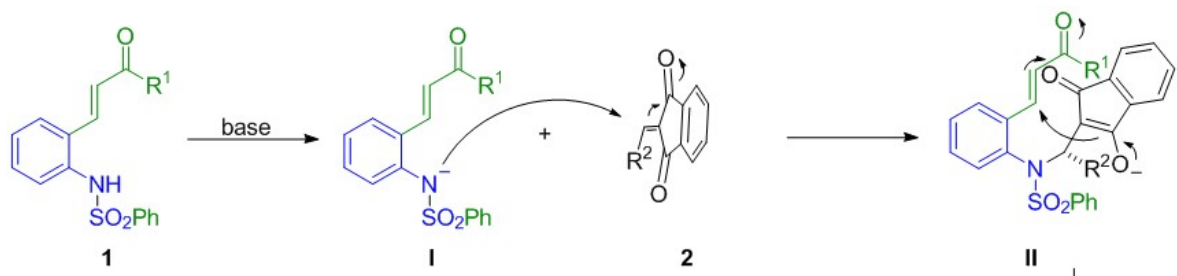<smiles>[R]C(=O)C[C@H]1c2ccccc2N(S(=O)(=O)c2ccccc2)[C@@]1(C(=O)O)c1ccccc1</smiles>

3<smiles>C=CC=C</smiles>

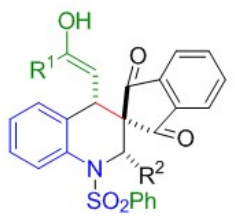

IV
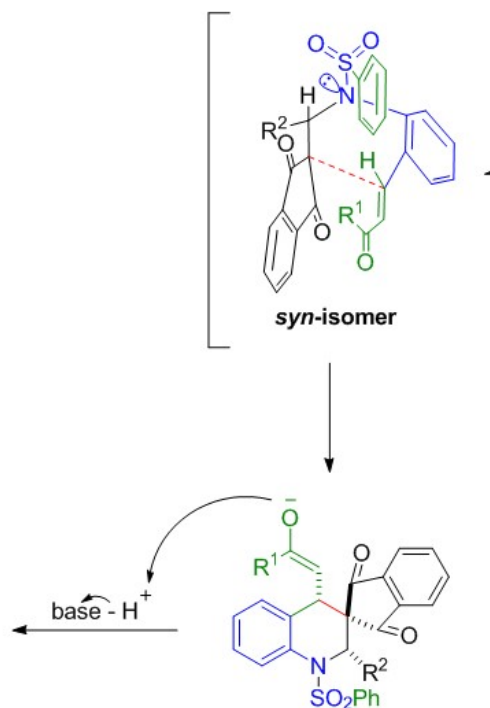

III

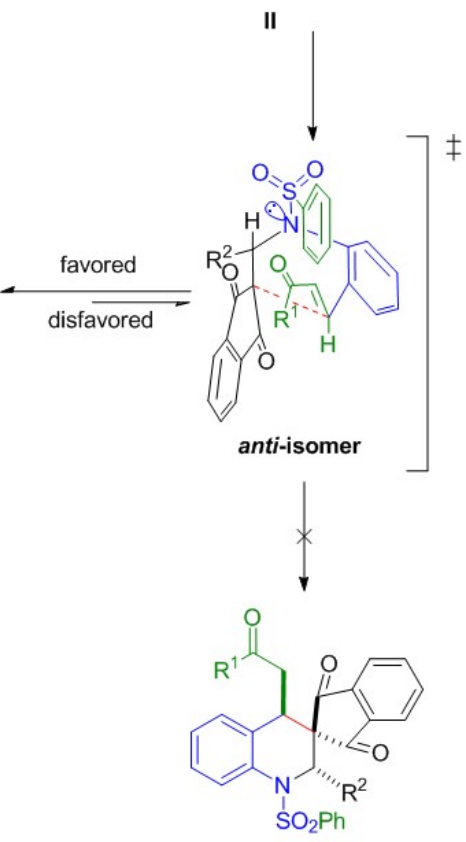

$3^{\prime}$

Scheme 1. Proposed mechanism of synthesizing spiro-tetrahydroquinolines by one-pot reaction.

As shown in Scheme 1, the transition states have two isomers (syn- and anti-isomers) that can interchange with each other. In the piperidine ring, if the green hydrogen atom heads upward (syn-isomer), the steric effect of the sulfonamide and enone moiety was less impact, and compound $\mathbf{3}$ was more easily formed. On the contrary, green enone moiety heads upward in the anti-isomer which shows more steric effect and makes it more difficult to form $3^{\prime}$.

In previous studies that have examined wound healing, most researchers have focused on natural products, such as extracts and extensions of Chinese herbal medicines or marine natural products. Only a few studies have examined the effects of synthetic chemicals on wound-healing outcomes. In this study, we explored the efficacy of wound healing by studying synthetic compounds and their related skeletal extensions. All compounds were preliminarily studied in human epidermal cells ( $\mathrm{HaCaT}$ ). Compound $\mathbf{3 i}$ was selected because, at low concentrations, the survival rate of cells was over $80 \%$. Compounds $3 \mathbf{b}$, $3 \mathbf{c}, 3 \mathbf{k}$, and $\mathbf{3 m}$ were shown to have less effect on the growth of $\mathrm{HaCaT}$ cells, based on the results of the MTT assay (Supplementary Figure S1). We performed a scratch analysis and observed that compound $3 \mathbf{i}$ has positive effects on wound healing. In the MTT assay, $3 \mathbf{i}$ displayed the significant inhibition of cell growth at the $25 \mu \mathrm{M}$ concentration. Due to the different outcomes observed for these two experiments, we considered whether $3 \mathbf{i}$ could be effective in animal models. Compared with $\mathbf{3 b}$ and $\mathbf{3 c}, \mathbf{3} \mathbf{i}$ was demonstrated to represent the best compound for healing wounds on mouse skin. The wound was completely healed by the 11th day in mice treated with $3 \mathbf{i}$. Based on the results of the MTT and wound-healing assay, $\mathbf{3} \mathbf{i}$ is thought to promote wound healing by promoting cell proliferation. In summary, 
we hope that the synthesis of spiro-tetrahydroqunioline derivatives might provide a new method for identifying chemicals for application in future wound-healing research.

\section{Materials and Methods}

All chemicals were analytical grade, purchased from Sigma-Aldrich (St. Louis, MO, USA), Alfa Aesar (Ward Hill, MA, USA), and Merck (Darmstadt, Germany). The purity of compounds was determined by TLC plates coated with Merck Silica gel 60 F254 (0.2 mm). Spots were observed under UV lamp or stained by dyeing agent. Infrared Spectroscopy (IR) were recorded on JASCOF/IR-5300 (Easton, MD, USA), polystyrene was used as internal standard to mark $1601 \mathrm{~cm}^{-1} \cdot{ }^{1} \mathrm{H}-\mathrm{NMR}$ and ${ }^{13} \mathrm{C}-\mathrm{NMR}$ spectra were recorded on Bruker Avance $400 \mathrm{MHz}$ spectrophotometer (Billerica, MA, USA). In ${ }^{1} \mathrm{H}-\mathrm{NMR}, \mathrm{CDCl}_{3}$ was used as d-solvent, TMS as internal standard to mark $0 \mathrm{ppm}$. The definition of splitting term: singlet (s), doublet $(\mathrm{d})$, triplet $(\mathrm{t})$, qutratet $(\mathrm{q})$, multiplet $(\mathrm{m})$, coupling constant $(J)$. In ${ }^{13} \mathrm{C}-\mathrm{NMR}$, chloroform was used as internal standard to mark $77.0 \mathrm{ppm}$. Mass Spectroscopy (MS) and High-Resolution Mass Spectroscopy (HRMS) were recorded on JMS-700 (JEOL), (Tokyo, Japan), double focusing mass spectrometer (FAB and EI), Applied Biosystems 4800 Proteomics Analyze (MALDI) (Foster City, CA, USA) or Waters (Milford, MA, USA) LCT Premier XE (ESI). X-ray spectra were recorded on Enraf-Nonius FR590 and Nonious CAD4 Kappa Axis XRD (Bruker). Dulbecco's Modified Eagle Medium (DMEM) and Penicillin-Streptomycin were purchased from Gibco (Waltham, MA, USA). Fetal Bovine Serum (FBS) was purchased from HyClone (Marlborough, MA, USA). Methythiazolyltetrazolium (MTT), Polyethylene glycol 400 (PEG 400), and Polyethylene glycol 4000 (PEG 4000) were purchased from Sigma-Aldrich. Culture insert for migration assay was purchased from ibidi (Planegg, Germany). Anesthesia for animal test (Zoletil) was purchased from Virbac (Carros, France). Fluorescence interpretation and image analysis were collected using Cytation ${ }^{\mathrm{TM}} 5$ Cell Imaging Multi-Mode Reader, BioTek (Winooski, VT, USA).

\subsection{Ortho-N-Protected Aminophenyl $\alpha, \beta$-Unsaturated Ketones (1)}

2-aminobenzyl alcohol (20 mmol, $2.46 \mathrm{~g}$ ) was dissolved in $100 \mathrm{~mL} \mathrm{DCM}$, and benzenesulfonyl chloride ( $22 \mathrm{mmol}, 4.18 \mathrm{~g}$ ) and $1 \mathrm{~mL}$ pyridine were added. The mixture was stirred for $12 \mathrm{~h}$ at r.t. The solvent was removed under reduced pressure. The residue 4 was not purified and dissolved in $50 \mathrm{~mL}$ DCM. Pyridinium chlorochromate $(30 \mathrm{mmol}, 6.46 \mathrm{~g})$ was added and the resulting solution was stirred at r.t. for $4 \mathrm{~h}$. The reaction mixture was filtered by Celite 545 and washed by DCM. After solvent was removed under reduced pressure, the residue was purified by flash chromatography (DCM: Hexanes $=2: 1$ ) to give 5 , yield $97 \%$. 5 ( $3 \mathrm{mmol}, 0.83 \mathrm{~g}$ ) was dissolved in $15 \mathrm{~mL}$ toluene, 6 ( $3.3 \mathrm{mmol}$ ) was added. The mixture was stirred at $80^{\circ} \mathrm{C}$ for $12 \mathrm{~h}$. The solvent was removed under reduced pressure, residue was purified by flash chromatography to yield $\mathbf{1}$ as shown in Scheme 2.

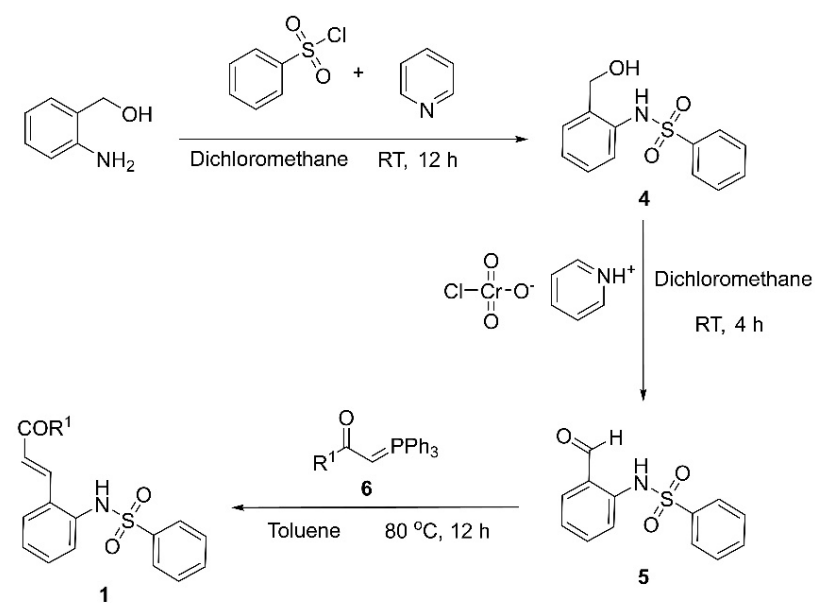

Scheme 2. The common synthesis of compound $\mathbf{1}$. 
(E)-N-(2-(3-oxo-3-phenylprop-1-en-1-yl)phenyl)benzenesulfonamide (1a)

(mp 147.3-148.2 $\left.{ }^{\circ} \mathrm{C}\right)$ :

${ }^{1} \mathrm{H}-\mathrm{NMR}\left(400 \mathrm{MHz}, \mathrm{CDCl}_{3}, 25{ }^{\circ} \mathrm{C}\right) \mathrm{\delta} / \mathrm{ppm}: 7.93(\mathrm{~d}, 2 \mathrm{H}, \mathrm{J}=8.2 \mathrm{~Hz}), 7.74(\mathrm{~d}, 1 \mathrm{H}$, $\mathrm{J}=15.8 \mathrm{~Hz}), 7.71-7.66(\mathrm{~m}, 2 \mathrm{H}), 7.65-7.55(\mathrm{~m}, 3 \mathrm{H}), 7.52-7.45(\mathrm{~m}, 3 \mathrm{H}), 7.39(\mathrm{t}, 1 \mathrm{H}, \mathrm{J}=7.8 \mathrm{~Hz})$, 7.36-7.21 (m, 4H), $7.20(\mathrm{~d}, 1 \mathrm{H}, \mathrm{J}=15.8 \mathrm{~Hz})$.

${ }^{13} \mathrm{C}-\mathrm{NMR}\left(100 \mathrm{MHz}, \mathrm{CDCl}_{3}, 25{ }^{\circ} \mathrm{C}\right)$ 8/ppm: 190.21, 139.1, 138.8, 137.6, 135.2, 133.1, $132.9,131.1,131.0,129.0,128.63,128.60,127.9,127.3,127.2,127.1,124.2$.

HRMS (ESI) for $\mathrm{C}_{21} \mathrm{H}_{18} \mathrm{NO}_{3} \mathrm{~S}$, [M + H] $]^{+}$(364.1002), found 364.1006.

IR $(\mathrm{KBr}) \bar{v}\left(\mathrm{~cm}^{-1}\right)$ : 3236, 3063, 2821, 1655, 1602, 1573, 1333, 1218, 1165, 1091, 734.

(E)-N-(2-(3-oxoprop-1-en-1-yl)phenyl)benzenesulfonamide (1b).

mp: $137.0-137.6^{\circ} \mathrm{C}$.

${ }^{1} \mathrm{H}-\mathrm{NMR}\left(400 \mathrm{MHz}, \mathrm{CDCl}_{3}, 25{ }^{\circ} \mathrm{C}\right) \mathrm{\delta} / \mathrm{ppm}$ : $9.50(\mathrm{~d}, 1 \mathrm{H}, \mathrm{J}=7.6 \mathrm{~Hz}), 7.71(\mathrm{~d}, 2 \mathrm{H}$, $\mathrm{J}=7.8 \mathrm{~Hz}), 7.64-7.54(\mathrm{~m}, 3 \mathrm{H}), 7.46(\mathrm{t}, 2 \mathrm{H}, \mathrm{J}=7.8 \mathrm{~Hz}), 7.38-7.30(\mathrm{~m}, 2 \mathrm{H}), 7.16-7.07(\mathrm{~m}, 2 \mathrm{H})$, $6.54\left(\mathrm{dd}, 1 \mathrm{H}, \mathrm{J}^{1}=15.8 \mathrm{~Hz}, \mathrm{~J}^{2}=7.8 \mathrm{~Hz}\right)$.

${ }^{13} \mathrm{C}-\mathrm{NMR}\left(100 \mathrm{MHz}, \mathrm{CDCl}_{3}, 25{ }^{\circ} \mathrm{C}\right)$ 8/ppm: 193.8, 147.2, 138.5, 134.5, 133.4, 131.7,

$131.4,129.9,129.2,128.3,128.0,127.4,127.3$.

IR (KBr) $\bar{v}\left(\mathrm{~cm}^{-1}\right): 3237,3063,2828,1671,1623,1448,1331,1160,1132,1091,972,758$. HRMS (ESI) for $\mathrm{C}_{15} \mathrm{H}_{13} \mathrm{NO}_{3} \mathrm{SNa}$, [M + Na] + (310.0508), found 310.0517 .

(E)-N-(2-(3-(4-bromophenyl)-3-oxoprop-1-en-1-yl)phenyl)benzenesulfonamide (1c). mp: $137.0-137.6^{\circ} \mathrm{C}$.

${ }^{1} \mathrm{H}-\mathrm{NMR}\left(400 \mathrm{MHz}, \mathrm{CDCl}_{3}, 2^{\circ}{ }^{\circ} \mathrm{C}\right)$ 8/ppm: 7.82-7.72 (m, 3H), $7.70(\mathrm{~d}, 2 \mathrm{H}, \mathrm{J}=7.8 \mathrm{~Hz})$, 7.63-7.58 (m, 3H), $7.55(\mathrm{~s}, 1 \mathrm{H}), 7.45-7.26(\mathrm{~m}, 6 \mathrm{H}), 7.16(\mathrm{~d}, 1 \mathrm{H}, \mathrm{J}=15.8 \mathrm{~Hz})$.

${ }^{13} \mathrm{C}-\mathrm{NMR}\left(\mathbf{1 0 0} \mathrm{MHz}, \mathrm{CDCl}_{3}, 25{ }^{\circ} \mathrm{C}\right) \mathrm{\delta} / \mathrm{ppm}: 189.2,139.8,138.9,136.3,135.2,133.0$, $131.9,131.3,131.0,130.1,129.0,128.2,127.8,127.3,127.2,123.7$.

IR (KBr) $\bar{v}\left(\mathrm{~cm}^{-1}\right): 3236,3072,2835,1654,1598,1397,1330,1216,1164,1091,758$.

HRMS (ESI) for $\mathrm{C}_{21} \mathrm{H}_{17} \mathrm{NO}_{3} \mathrm{~S}^{79} \mathrm{Br}$, [M + H] ${ }^{+}$(442.0107), found 442.0111 .

HRMS (ESI) for $\mathrm{C}_{21} \mathrm{H}_{17} \mathrm{NO}_{3} \mathrm{~S}^{81} \mathrm{Br}$, [M + H] ${ }^{+}$(444.0087), found 442.0093 .

(E)-N-(2-(3-(4-nitrophenyl)-3-oxoprop-1-en-1-yl)phenyl)benzenesulfonamide (1d).

mp: $185.4-185.7^{\circ} \mathrm{C}$.

${ }^{1} \mathrm{H}$-NMR $\left(400 \mathrm{MHz}, \mathrm{CDCl}_{3}, 25{ }^{\circ} \mathrm{C}\right) \mathrm{\delta} / \mathrm{ppm}: 8.37(\mathrm{~d}, 2 \mathrm{H}, \mathrm{J}=8.8 \mathrm{~Hz}), 8.13(\mathrm{~d}, 2 \mathrm{H}$, $\mathrm{J}=8.8 \mathrm{~Hz}), 7.81(\mathrm{~d}, 1 \mathrm{H}, \mathrm{J}=15.8 \mathrm{~Hz}), 7.75-7.68(\mathrm{~m}, 3 \mathrm{H}), 7.54-7.34(\mathrm{~m}, 6 \mathrm{H}), 7.27-7.24(\mathrm{~m}, 1 \mathrm{H})$, $6.73(\mathrm{~s}, 1 \mathrm{H})$.

${ }^{13}$ C-NMR (100 MHz, $\left.\mathrm{CDCl}_{3}, 25{ }^{\circ} \mathrm{C}\right)$ 8/ppm: 189.0, 150.2, 142.5, 141.1, 138.7, 135.1, $133.2,131.7,131.0,129.6,129.2,127.7,127.4,127.3,123.9$.

IR (KBr) $\bar{v}\left(\mathrm{~cm}^{-1}\right): 3253,3068,2926,1664,1597,1523,1329,1212,1162,1090,734$.

HRMS (ESI) for $\mathrm{C}_{21} \mathrm{H}_{17} \mathrm{~N}_{2} \mathrm{O}_{5} \mathrm{~S}$, [M + H] $]^{+}$(409.0853), found 409.0856.

(E)-N-(2-(3-(4-methoxyphenyl)-3-oxoprop-1-en-1-yl)phenyl)benzenesulfonamide (1e). mp: $171.8-172.0^{\circ} \mathrm{C}$.

${ }^{1} \mathrm{H}-\mathrm{NMR}\left(400 \mathrm{MHz}, \mathrm{CDCl}_{3}, 2^{\circ}{ }^{\circ} \mathrm{C}\right)$ 8/ppm: $7.95(\mathrm{~d}, 2 \mathrm{H}, \mathrm{J}=7.8 \mathrm{~Hz}), 7.83(\mathrm{~s}, 1 \mathrm{H}), 7.75$ $(\mathrm{d}, 1 \mathrm{H}, \mathrm{J}=15.8 \mathrm{~Hz}), 7.71-7.65(\mathrm{~m}, 2 \mathrm{H}), 7.59-7.50(\mathrm{~m}, 2 \mathrm{H}), 7.39(\mathrm{t}, 1 \mathrm{H}, \mathrm{J}=7.8 \mathrm{~Hz}), 7.35-7.23$ $(\mathrm{m}, 4 \mathrm{H}), 7.18(\mathrm{~d}, 1 \mathrm{H}, \mathrm{J}=15.8 \mathrm{~Hz}), 6.95(\mathrm{~d}, 2 \mathrm{H}, \mathrm{J}=7.8 \mathrm{~Hz}), 3.88(\mathrm{~s}, 3 \mathrm{H})$.

${ }^{13} \mathrm{C}-\mathrm{NMR}\left(\mathbf{1 0 0} \mathrm{MHz}, \mathrm{CDCl}_{3}, 25{ }^{\circ} \mathrm{C}\right)$ 8/ppm: 188.4, 163.6, 138.9, 138.3, 135.1, 132.9, 131.1, 131.0, 130.9, 130.5, 129.0, 127.8, 127.2, 127.1, 124.2, 113.9, 55.5.

IR (KBr) $\bar{v}\left(\mathrm{~cm}^{-1}\right): 3182,3068,2840,1651,1603,1335,1263,1223,1167,1091,1022,760$. HRMS (ESI) for $\mathrm{C}_{22} \mathrm{H}_{20} \mathrm{NO}_{4} \mathrm{~S},[\mathrm{M}+\mathrm{H}]^{+}$(394.1108), found 394.1114.

Ethyl-(E)-3-(2-(phenylsulfonamido)phenyl)acrylate (1f).

mp: $125.1-125.6^{\circ} \mathrm{C}$.

${ }^{1} \mathrm{H}$-NMR $\left(400 \mathrm{MHz}, \mathrm{CDCl}_{3}, 25{ }^{\circ} \mathrm{C}\right) \mathrm{\delta} / \mathrm{ppm}: 7.68(\mathrm{~d}, 2 \mathrm{H}, \mathrm{J}=8.0 \mathrm{~Hz}), 7.56(\mathrm{~d}, 1 \mathrm{H}$, $\mathrm{J}=15.8 \mathrm{~Hz}), 7.50(\mathrm{t}, 1 \mathrm{H}, \mathrm{J}=7.6 \mathrm{~Hz}), 7.47-7.42(\mathrm{~m}, 2 \mathrm{H}), 7.42-7.33(\mathrm{~m}, 3 \mathrm{H}), 7.27-7.21(\mathrm{~m}, 2 \mathrm{H})$, $6.12(\mathrm{~d}, 1 \mathrm{H}, \mathrm{J}=15.8 \mathrm{~Hz}), 4.23(\mathrm{q}, 2 \mathrm{H}, \mathrm{J}=7.2 \mathrm{~Hz}), 1.32(\mathrm{t}, 3 \mathrm{H}, \mathrm{J}=7.2 \mathrm{~Hz})$.

${ }^{13} \mathrm{C}-\mathrm{NMR}\left(100 \mathrm{MHz}, \mathrm{CDCl}_{3}, 25{ }^{\circ} \mathrm{C}\right) \mathrm{\delta} / \mathrm{ppm}: 166.5,138.8,134.5,133.0,130.9,130.4$, $129.0,127.5,127.3,127.2,127.0,120.7,60.8,14.2$.

IR $(\mathrm{KBr}) \bar{v}\left(\mathrm{~cm}^{-1}\right): 3244,3068,2983,1692,1635,1448,1320,1166,1091,979,762$. HRMS (ESI) for $\mathrm{C}_{17} \mathrm{H}_{17} \mathrm{NO}_{4} \mathrm{SNa}$, [M + Na]+ (354.0770), found 354.0775. 
(E)-N-(2-(3-(naphthalen-2-yl)-3-oxoprop-1-en-1-yl)phenyl)benzenesulfonamide (1g). mp: $161.2-161.5^{\circ} \mathrm{C}$.

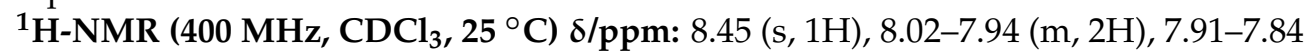
$(\mathrm{m}, 2 \mathrm{H}), 7.77(\mathrm{~d}, 1 \mathrm{H}, \mathrm{J}=15.8 \mathrm{~Hz}), 7.73-7.67(\mathrm{~m}, 2 \mathrm{H}), 7.67-7.53(\mathrm{~m}, 3 \mathrm{H}), 7.51-7.43(\mathrm{~m}, 2 \mathrm{H})$, 7.43-7.25 (m, 6H).

${ }^{13} \mathrm{C}-\mathrm{NMR}\left(100 \mathrm{MHz} \mathrm{CDCl}_{3}, 25{ }^{\circ} \mathrm{C}\right)$ 8/ppm: 190.0, 139.0, 138.9, 135.6, 135.2, 134.9, 133.0, 132.5, 131.2, 131.1, 130.4, 129.6, 129.1, 128.7, 128.6, 127.8, 127.3, 127.2, 126.9, 124.5, 124.4.

IR (KBr) $\bar{v}\left(\mathrm{~cm}^{-1}\right):$ 3213, 3063, 2813, 1653, 1626, 1598, 1485, 1327, 1165, 1091, 759.

HRMS (ESI) for $\mathrm{C}_{25} \mathrm{H}_{20} \mathrm{NO}_{3} \mathrm{~S},[\mathrm{M}+\mathrm{H}]^{+}$(414.1158), found 414.1164.

\subsection{2-Arylidene-1,3-Indandiones (2)}

A solution of the mixture of 1,3-indandione ( $5 \mathrm{mmol}, 0.73 \mathrm{~g})$, aldehyde $(5.5 \mathrm{mmol})$ and L-proline $(1.5 \mathrm{mmol}, 0.17 \mathrm{~g})$ in methanol $(90 \mathrm{~mL})$ was stirred for $12 \mathrm{~h}$ at r.t. The solvent was removed under reduced pressure, and the residue was washed by methanol. The solid 2 was purified by flash chromatography as shown in Scheme 3.<smiles>O=C1CC(=O)c2ccccc21</smiles><smiles>[R]C=O</smiles><smiles>O=C(O)[C@@H]1CCCN1</smiles>

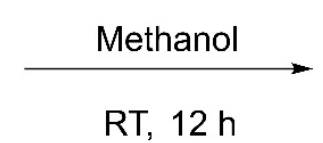<smiles>[R]C=C1C(=O)c2ccccc2C1=O</smiles>

Scheme 3. The common synthesis of compound 2.

\subsection{Spiro-Tetrahydroquinoline (3)}

Compounds $1(0.2 \mathrm{mmol})$ and $2(0.2 \mathrm{mmol})$ were dissolved in $1 \mathrm{~mL}$ DCM, $1.2 \mathrm{mg}$ $\operatorname{DABCO}(5 \mathrm{~mol} \%)$ was added as catalysis. The reaction was sealed and stirred at $30^{\circ} \mathrm{C}$. After the reaction completed, the mixture was quenched with $1 \mathrm{~N}$ hydrochloric acid aqueous solution and extracted with DCM. The organic layer was washed with water, dried over $\mathrm{MgSO}_{4}$, filtered, re-crystallized in ethanol and hexane.

3a (110.0 mg, yield 92\%, mp 243-244 $\left.{ }^{\circ} \mathrm{C}\right)$ : 1a $(72.7 \mathrm{mg}, 0.2 \mathrm{mmol})$ and 2a $(46.9 \mathrm{mg}$, $0.2 \mathrm{mmol}$ ) as starting material, reacted for $12 \mathrm{~h}$.

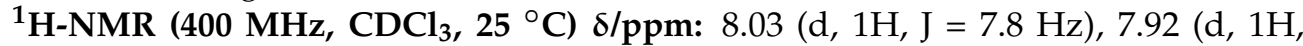
$\mathrm{J}=7.6 \mathrm{~Hz}), 7.78-7.69(\mathrm{~m}, 3 \mathrm{H}), 7.69-7.60(\mathrm{~m}, 3 \mathrm{H}), 7.59-7.44(\mathrm{~m}, 6 \mathrm{H}), 7.37(\mathrm{t}, 2 \mathrm{H}, \mathrm{J}=7.8 \mathrm{~Hz})$, $7.20(\mathrm{t}, 1 \mathrm{H}, \mathrm{J}=7.6 \mathrm{~Hz}), 7.07-6.94(\mathrm{~m}, 5 \mathrm{H}), 6.68(\mathrm{~d}, 1 \mathrm{H}, \mathrm{J}=8.0 \mathrm{~Hz}), 5.87(\mathrm{~s}, 1 \mathrm{H}), 3.05(\mathrm{~d}, 1 \mathrm{H}$, $\mathrm{J}=11 \mathrm{~Hz}), 2.95\left(\mathrm{dd}, 1 \mathrm{H}, \mathrm{J}^{1}=16.4 \mathrm{~Hz}, \mathrm{~J}^{2}=11 \mathrm{~Hz}\right), 2.34\left(\mathrm{dd}, 1 \mathrm{H}, \mathrm{J}^{1}=16.4 \mathrm{~Hz}, \mathrm{~J}^{2}=2.0 \mathrm{~Hz}\right)$.

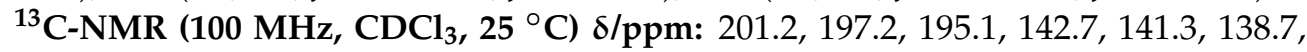
137.6, 137.3, 136.5, 135.9, 135.8, 133.5, 133.4, 133.3, 129.2, 128.7, 128.1, 127.9, 127.8, 127.7, $127.5,127.1,126.8,125.3,123.03,122.98,66.1,66.0,37.3,36.3$.

HRMS (ESI) for $\mathrm{C}_{37} \mathrm{H}_{27} \mathrm{NO}_{5} \mathrm{~S},[\mathrm{M}+\mathrm{Na}]^{+}(620.1508)$, found 620.1509 .

IR (KBr) $\bar{v}\left(\mathrm{~cm}^{-1}\right):$ 3440, 1741, 1705, 1448, 1356, 1250, 1169, 1093, 753, 582.

3b (96.1 mg, yield 71\%, mp 229-230 $\left.{ }^{\circ} \mathrm{C}\right): \mathbf{1 a}(72.7 \mathrm{mg}, 0.2 \mathrm{mmol})$ and $2 \mathbf{b}(62.3 \mathrm{mg}$, $0.2 \mathrm{mmol}$ ) as starting material, reacted for $24 \mathrm{~h}$.

${ }^{1} \mathrm{H}-\mathrm{NMR}\left(400 \mathrm{MHz}, \mathrm{CDCl}_{3}, 25^{\circ} \mathrm{C}\right)$ 8/ppm: $7.97(\mathrm{~d}, 1 \mathrm{H}, \mathrm{J}=7.6 \mathrm{~Hz}), 7.92(\mathrm{dd}, 1 \mathrm{H}$, $\left.\mathrm{J}^{1}=7.6 \mathrm{~Hz}, \mathrm{~J}^{2}=1.2 \mathrm{~Hz}\right), 7.84-7.79(\mathrm{~m}, 2 \mathrm{H}), 7.76\left(\mathrm{td}, 1 \mathrm{H}, \mathrm{J}^{1}=7.2 \mathrm{~Hz}, \mathrm{~J}^{2}=0.8 \mathrm{~Hz}\right), 7.71-7.67$ $(\mathrm{m}, 2 \mathrm{H}), 7.64\left(\mathrm{td}, 1 \mathrm{H}, \mathrm{J}^{1}=7.6 \mathrm{~Hz}, \mathrm{~J}^{2}=0.8 \mathrm{~Hz}\right), 7.62-7.55(\mathrm{~m}, 3 \mathrm{H}), 7.52(\mathrm{t}, 1 \mathrm{H}, \mathrm{J}=7.6 \mathrm{~Hz}), 7.47$ $(\mathrm{t}, 1 \mathrm{H}, \mathrm{J}=7.6 \mathrm{~Hz}), 7.43-7.34(\mathrm{~m}, 3 \mathrm{H}), 7.28-7.20(\mathrm{~m}, 2 \mathrm{H}), 7.14-7.06(\mathrm{~m}, 2 \mathrm{H}), 6.89-6.82(\mathrm{~m}, 1 \mathrm{H})$, $6.77(\mathrm{~d}, 1 \mathrm{H}, \mathrm{J}=7.8 \mathrm{~Hz}), 6.29(\mathrm{~s}, 1 \mathrm{H}), 3.14-3.00(\mathrm{~m}, 2 \mathrm{H}), 2.33(\mathrm{~d}, 1 \mathrm{H}, \mathrm{J}=16 \mathrm{~Hz})$.

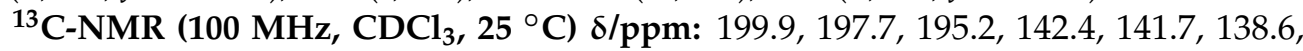
$137.9,137.0,136.3,135.9,134.1,133.4,132.0,131.5,129.4,129.0,128.6,128.04,127.92,127.7$, $127.4,127.2,127.0,125.6,123.4,122.7,121.7,66.1,63.3,36.3,36.0$.

HRMS (ESI) for $\mathrm{C}_{37} \mathrm{H}_{26} \mathrm{Br}^{79} \mathrm{NO}_{5} \mathrm{~S},[\mathrm{M}+\mathrm{Na}]^{+}$(698.0607), found 698.0612. HRMS (ESI) for $\mathrm{C}_{37} \mathrm{H}_{26} \mathrm{Br}^{81} \mathrm{NO}_{5} \mathrm{~S},[\mathrm{M}+\mathrm{Na}]^{+}$(700.0587), found 700.0599. 
IR $(\mathrm{KBr}) \bar{v}\left(\mathrm{~cm}^{-1}\right):$ 3066, 1742, 1707, 1594, 1448, 1358, 1251, 1171, 1090, 949, 754.

3c (109.6 mg, yield 81\%, mp 254-255 $\left.{ }^{\circ} \mathrm{C}\right): 1 \mathrm{a}(72.7 \mathrm{mg}, 0.2 \mathrm{mmol})$ and 2c (62.3 mg, $0.2 \mathrm{mmol}$ ) as starting material, reacted for $3 \mathrm{~h}$.

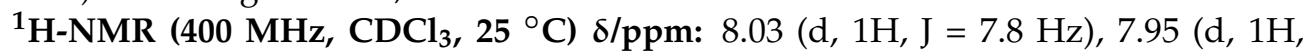
$\mathrm{J}=7.8 \mathrm{~Hz}), 7.79(\mathrm{t}, 1 \mathrm{H}, \mathrm{J}=7.4 \mathrm{~Hz}), 7.76-7.67(\mathrm{~m}, 3 \mathrm{H}), 7.65-7.46(\mathrm{~m}, 8 \mathrm{H}), 7.37(\mathrm{t}, 2 \mathrm{H}$, $\mathrm{J}=7.4 \mathrm{~Hz}), 7.21(\mathrm{t}, 1 \mathrm{H}, \mathrm{J}=7.4 \mathrm{~Hz}), 7.17-7.08(\mathrm{~m}, 2 \mathrm{H}), 7.04(\mathrm{~d}, 1 \mathrm{H}, \mathrm{J}=7.4 \mathrm{~Hz}), 6.92(\mathrm{t}, 1 \mathrm{H}$, $\mathrm{J}=7.6 \mathrm{~Hz}), 6.66(\mathrm{~d}, 1 \mathrm{H}, \mathrm{J}=7.6 \mathrm{~Hz}), 5.80(\mathrm{~s}, 1 \mathrm{H}), 3.08-2.87(\mathrm{~m}, 2 \mathrm{H}), 2.33(\mathrm{~d}, 1 \mathrm{H}, \mathrm{J}=16.0 \mathrm{~Hz})$.

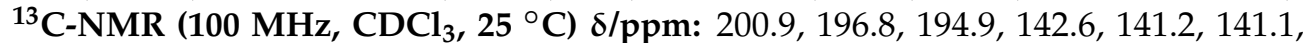
137.3, 137.1, 136.7, 136.1, 135.8, 133.5, 133.3, 130.8, 129.80, 129.77, 129.30, 128.7, 128.0, 127.9, 127.7, 127.1, 126.9, 125.6, 125.3, 123.2, 123.1, 122.1, 65.8, 65.3, 37.4, 36.3.

HRMS (ESI) for $\mathrm{C}_{37} \mathrm{H}_{26} \mathrm{Br}^{79} \mathrm{NO}_{5} \mathrm{~S},[\mathrm{M}+\mathrm{Na}]^{+}$(698.0607), found 698.0613.

HRMS (ESI) for $\mathrm{C}_{37} \mathrm{H}_{26} \mathrm{Br}^{81} \mathrm{NO}_{5} \mathrm{~S},[\mathrm{M}+\mathrm{Na}]^{+}$(700.0587), found 700.0601.

IR $(\mathrm{KBr}) \bar{v}\left(\mathrm{~cm}^{-1}\right):$ 3064, 1741, 1707, 1594, 1448, 1357, 1250, 1169, 1090, 915, 732.

3d (112.3 mg, yield 83\%, mp 249-250 $\left.{ }^{\circ} \mathrm{C}\right): \mathbf{1 a}(72.7 \mathrm{mg}, 0.2 \mathrm{mmol})$ and $\mathbf{2 d}(62.3 \mathrm{mg}$, $0.2 \mathrm{mmol}$ ) as starting material, reacted for $3 \mathrm{~h}$.

${ }^{1} \mathrm{H}-\mathrm{NMR}\left(400 \mathrm{MHz}, \mathrm{CDCl}_{3}, 25{ }^{\circ} \mathrm{C}\right)$ //ppm: $8.01(\mathrm{~d}, 1 \mathrm{H}, \mathrm{J}=8.0 \mathrm{~Hz}), 7.92(\mathrm{~d}, 1 \mathrm{H}$, $\mathrm{J}=7.6 \mathrm{~Hz}), 7.80(\mathrm{t}, 1 \mathrm{H}, \mathrm{J}=7.6 \mathrm{~Hz}), 7.75-7.66(\mathrm{~m}, 3 \mathrm{H}), 7.64-7.44(\mathrm{~m}, 8 \mathrm{H}), 7.36(\mathrm{t}, 2 \mathrm{H}$, $\mathrm{J}=7.6 \mathrm{~Hz}), 7.20(\mathrm{t}, 1 \mathrm{H}, \mathrm{J}=7.6 \mathrm{~Hz}), 7.15(\mathrm{~d}, 2 \mathrm{H}, \mathrm{J}=8.4 \mathrm{~Hz}), 6.95(\mathrm{~d}, 2 \mathrm{H}, \mathrm{J}=8.4 \mathrm{~Hz}), 6.65(\mathrm{~d}$, $1 \mathrm{H}, \mathrm{J}=7.4 \mathrm{~Hz}), 5.83(\mathrm{~s}, 1 \mathrm{H}), 3.02(\mathrm{~d}, 1 \mathrm{H}, \mathrm{J}=11 \mathrm{~Hz}), 2.92\left(\mathrm{dd}, 1 \mathrm{H}, \mathrm{J}^{1}=16.4 \mathrm{~Hz}, \mathrm{~J}^{2}=11 \mathrm{~Hz}\right)$, $2.32\left(\mathrm{dd}, 1 \mathrm{H}, \mathrm{J}^{1}=16.4 \mathrm{~Hz}, \mathrm{~J}^{2}=1.8 \mathrm{~Hz}\right)$.

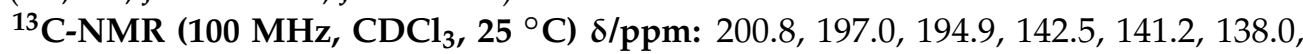
$137.4,137.2,136.8,136.2,135.8,133.45,133.40,133.2,131.3,129.3,128.7,128.6,127.9,127.8$, 127.6, 127.1, 126.9125.3, 123.3, 123.1, 121.6, 65.7, 65.3, 37.6, 36.2.

HRMS (ESI) for $\mathrm{C}_{37} \mathrm{H}_{26} \mathrm{Br}^{79} \mathrm{NO}_{5} \mathrm{~S},[\mathrm{M}+\mathrm{Na}]^{+}$(698.0607), found 698.0610.

HRMS (ESI) for $\mathrm{C}_{37} \mathrm{H}_{26} \mathrm{Br}^{81} \mathrm{NO}_{5} \mathrm{~S},[\mathrm{M}+\mathrm{Na}]^{+}(700.0587)$, found 700.0598.

IR $(\mathrm{KBr}) \bar{v}\left(\mathrm{~cm}^{-1}\right):$ 3068, 1741, 1707, 1594, 1488, 1356, 1250, 1169, 1073, 753.

3e (108.7 mg, yield $86 \%$, mp $\left.253-254^{\circ} \mathrm{C}\right): \mathbf{1 a}(72.7 \mathrm{mg}, 0.2 \mathrm{mmol})$ and $2 \mathbf{e}(53.7 \mathrm{mg}$, $0.2 \mathrm{mmol}$ ) as starting material, reacted for $3 \mathrm{~h}$.

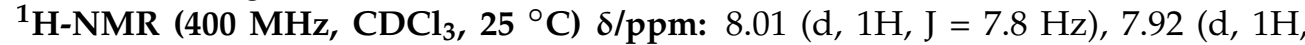
$\mathrm{J}=7.8 \mathrm{~Hz}), 7.78\left(\mathrm{td}, 1 \mathrm{H}, \mathrm{J}^{1}=7.6 \mathrm{~Hz}, \mathrm{~J}^{2}=0.8 \mathrm{~Hz}\right), 7.75-7.67(\mathrm{~m}, 3 \mathrm{H}), 7.65-7.44(\mathrm{~m}, 8 \mathrm{H}), 7.36$ $(\mathrm{t}, 2 \mathrm{H}, \mathrm{J}=7.6 \mathrm{~Hz}), 7.20(\mathrm{t}, 1 \mathrm{H}, \mathrm{J}=7.6 \mathrm{~Hz}), 7.04-6.96(\mathrm{~m}, 4 \mathrm{H}), 6.66(\mathrm{~d}, 1 \mathrm{H}, \mathrm{J}=7.6 \mathrm{~Hz}), 5.84(\mathrm{~s}$, $1 \mathrm{H}), 3.02(\mathrm{~d}, 1 \mathrm{H}, \mathrm{J}=11 \mathrm{~Hz}), 2.93\left(\mathrm{dd}, 1 \mathrm{H}, \mathrm{J}^{1}=16.4 \mathrm{~Hz}, \mathrm{~J}^{2}=11 \mathrm{~Hz}\right), 2.32\left(\mathrm{dd}, 1 \mathrm{H}, \mathrm{J}^{1}=16.4 \mathrm{~Hz}\right.$, $\left.\mathrm{J}^{2}=1.6 \mathrm{~Hz}\right)$.

${ }^{13} \mathrm{C}-\mathrm{NMR}\left(100 \mathrm{MHz} \mathrm{CDCl}_{3}, 25{ }^{\circ} \mathrm{C}\right)$ 8/ppm: 200.9, 197.0, 194.9, 142.6, 141.2, 137.5, $137.4,137.2,136.7,136.1,135.8,133.5,133.4,133.2,129.3,128.7,128.4,128.3,127.9,127.8$, 127.6127.1, 126.9, 125.3, 123.3, 123.1, 65.8, 65.3, 37.5, 36.2 .

HRMS (ESI) for $\mathrm{C}_{37} \mathrm{H}_{26} \mathrm{Cl}^{35} \mathrm{NO}_{5} \mathrm{~S},[\mathrm{M}+\mathrm{Na}]^{+}$(654.1112), found 654.1118.

HRMS (ESI) for $\mathrm{C}_{37} \mathrm{H}_{26} \mathrm{Cl}^{37} \mathrm{NO}_{5} \mathrm{~S},[\mathrm{M}+\mathrm{Na}]^{+}$(655.1146), found 656.1104.

IR $(\mathrm{KBr}) \bar{v}\left(\mathrm{~cm}^{-1}\right): 3112,1739,1707,1583,1355,1250,1170,752$.

3f (100.9 mg, yield 81\%, mp 239-240 $\left.{ }^{\circ} \mathrm{C}\right): \mathbf{1 a}(72.7 \mathrm{mg}, 0.2 \mathrm{mmol})$ and $2 \mathrm{f}(51.9 \mathrm{mg}$, $0.2 \mathrm{mmol}$ ) as starting material, reacted for $3 \mathrm{~h}$.

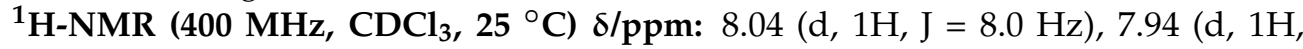
$\mathrm{J}=7.8 \mathrm{~Hz}), 7.81(\mathrm{t}, 1 \mathrm{H}, \mathrm{J}=7.4 \mathrm{~Hz}), 7.74(\mathrm{t}, 1 \mathrm{H}, \mathrm{J}=7.6 \mathrm{~Hz}), 7.70(\mathrm{~d}, 2 \mathrm{H}, \mathrm{J}=7.6 \mathrm{~Hz}), 7.65-7.58$ $(\mathrm{m}, 3 \mathrm{H}), 7.58-7.46(\mathrm{~m}, 5 \mathrm{H}), 7.42-7.30(\mathrm{~m}, 4 \mathrm{H}), 7.24-7.16(\mathrm{~m}, 3 \mathrm{H}), 6.65(\mathrm{~d}, 1 \mathrm{H}, \mathrm{J}=7.8 \mathrm{~Hz})$, $5.91(\mathrm{~s}, 1 \mathrm{H}), 3.03(\mathrm{~d}, 1 \mathrm{H}, \mathrm{J}=11 \mathrm{~Hz}), 2.93\left(\mathrm{dd}, 1 \mathrm{H}, \mathrm{J}^{1}=16.4 \mathrm{~Hz}, \mathrm{~J}^{2}=11 \mathrm{~Hz}\right), 2.32(\mathrm{dd}, 1 \mathrm{H}$, $\left.\mathrm{J}^{1}=16.4 \mathrm{~Hz}, \mathrm{~J}^{2}=1.6 \mathrm{~Hz}\right)$.

${ }^{13}$ C-NMR (100 MHz, $\left.\mathrm{CDCl}_{3}, 25{ }^{\circ} \mathrm{C}\right)$ 8/ppm: 200.4, 196.7, 194.7, 144.3, 142.3, 141.1, $137.1,136.99$, 136.96, 136.4, 135.7, 133.6, 133.5, 132.9, 132.0, 129.4, 128.7, 128.1, 127.8, 127.6, $127.5,127.1,125.3,123.29,123.23,118.3,111.5,65.6,65.2,37.7,36.1$.

HRMS (ESI) for $\mathrm{C}_{38} \mathrm{H}_{26} \mathrm{~N}_{2} \mathrm{O}_{5} \mathrm{~S},[\mathrm{M}+\mathrm{Na}]^{+}(645.1455)$, found 645.1459.

IR $(\mathrm{KBr}) \overline{v v}\left(\mathrm{~cm}^{-1}\right): 3485,2356,1736,1707,1360,1250,1170,749,581$.

$3 \mathrm{~g}$ (105.4 mg, yield 82\%, mp 247-248 $\left.{ }^{\circ} \mathrm{C}\right): \mathbf{1 a}(72.7 \mathrm{mg}, 0.2 \mathrm{mmol})$ and $\mathbf{2 g}(55.9 \mathrm{mg}$, $0.2 \mathrm{mmol}$ ) as starting material, reacted for $3 \mathrm{~h}$. 


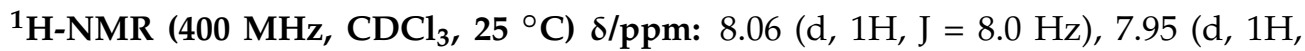
$\mathrm{J}=7.6 \mathrm{~Hz}), 7.91(\mathrm{~d}, 2 \mathrm{H}, \mathrm{J}=8.6 \mathrm{~Hz}), 7.81(\mathrm{t}, 1 \mathrm{H}, \mathrm{J}=7.4 \mathrm{~Hz}), 7.76-7.67(\mathrm{~m}, 3 \mathrm{H}), 7.65-7.58(\mathrm{~m}$, $3 \mathrm{H}), 7.58-7.47(\mathrm{~m}, 5 \mathrm{H}), 7.36(\mathrm{t}, 2 \mathrm{H}, \mathrm{J}=7.8 \mathrm{~Hz}), 7.31-7.25(\mathrm{~m}, 2 \mathrm{H}), 7.22(\mathrm{t}, 1 \mathrm{H}, \mathrm{J}=7.6 \mathrm{~Hz}), 6.66$ $(\mathrm{d}, 1 \mathrm{H}, \mathrm{J}=7.6 \mathrm{~Hz}), 5.97(\mathrm{~s}, 1 \mathrm{H}), 3.04(\mathrm{~d}, 1 \mathrm{H}, \mathrm{J}=11 \mathrm{~Hz}), 2.94\left(\mathrm{dd}, 1 \mathrm{H}, \mathrm{J}^{1}=16.4 \mathrm{~Hz}, \mathrm{~J}^{2}=11 \mathrm{~Hz}\right)$, $2.33\left(\mathrm{dd}, 1 \mathrm{H}, \mathrm{J}^{1}=16.4 \mathrm{~Hz}, \mathrm{~J}^{2}=1.8 \mathrm{~Hz}\right)$.

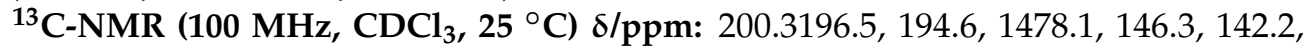
141.0, 137.1, 137.0, 136.9, 136.5, 135.7, 133.6, 133.5, 132.8, 129.4, 128.7, 128.1, 127.9, 127.8, $127.5,127.1,125.3,123.4,123.31,123.26,65.6,64.9,37.8,36.1$.

HRMS (ESI) for $\mathrm{C}_{37} \mathrm{H}_{26} \mathrm{~N}_{2} \mathrm{O}_{7} \mathrm{~S},\left[\mathrm{M}+\mathrm{Na}{ }^{+}(665.1353)\right.$, found 665.1359 .

IR (KBr) $\bar{v}\left(\mathrm{~cm}^{-1}\right):$ 3068, 1743, 1708, 1598, 1522, 1340, 1250, 1169, 1088, 689.

3h (85.4 mg, yield 68\%, mp 241-242 $\left.{ }^{\circ} \mathrm{C}\right)$ : $\mathbf{1 a}(72.7 \mathrm{mg}, 0.2 \mathrm{mmol})$ and $2 \mathrm{~h}(52.9 \mathrm{mg}$, $0.2 \mathrm{mmol}$ ) as starting material, reacted for $29 \mathrm{~h}$.

${ }^{1} \mathrm{H}-\mathrm{NMR}\left(400 \mathrm{MHz} \mathrm{CDCl}_{3}, 25^{\circ} \mathrm{C}\right) \mathrm{\delta} / \mathbf{p p m}: 8.00\left(\mathrm{dd}, 1 \mathrm{H}, \mathrm{J}^{1}=8.0 \mathrm{~Hz}, \mathrm{~J}^{2}=1.2 \mathrm{~Hz}\right), 7.91$ $(\mathrm{d}, 1 \mathrm{H}, \mathrm{J}=7.6 \mathrm{~Hz}), 7.75\left(\mathrm{td}, 1 \mathrm{H}, \mathrm{J}^{1}=7.2 \mathrm{~Hz}, \mathrm{~J}^{2}=1.2 \mathrm{~Hz}\right), 7.72-7.60(\mathrm{~m}, 5 \mathrm{H}), 7.59-7.43(\mathrm{~m}, 6 \mathrm{H})$, $7.36(\mathrm{t}, 2 \mathrm{H}, \mathrm{J}=7.6 \mathrm{~Hz}), 7.19\left(\mathrm{td}, 1 \mathrm{H}, \mathrm{J}^{1}=7.8 \mathrm{~Hz}, \mathrm{~J}^{2}=1.2 \mathrm{~Hz}\right), 6.96(\mathrm{~d}, 2 \mathrm{H}, \mathrm{J}=8.6 \mathrm{~Hz}), 6.67(\mathrm{~d}$, $1 \mathrm{H}, \mathrm{J}=7.6 \mathrm{~Hz}), 6.54(\mathrm{~d}, 2 \mathrm{H}, \mathrm{J}=8.6 \mathrm{~Hz}), 5.83(\mathrm{~s}, 1 \mathrm{H}), 3.61(\mathrm{~s}, 3 \mathrm{H}), 3.04(\mathrm{~d}, 1 \mathrm{H}, \mathrm{J}=11 \mathrm{~Hz}), 2.93$ $\left(\mathrm{dd}, 1 \mathrm{H}, \mathrm{J}^{1}=16.4 \mathrm{~Hz}, \mathrm{~J}^{2}=11 \mathrm{~Hz}\right), 2.33\left(\mathrm{dd}, 1 \mathrm{H}, \mathrm{J}^{1}=16.4 \mathrm{~Hz}, \mathrm{~J}^{2}=2.0 \mathrm{~Hz}\right)$.

${ }^{13}$ C-NMR (100 MHz, $\left.\mathrm{CDCl}_{3}, 25{ }^{\circ} \mathrm{C}\right)$ S/ppm: 201.3, 197.3, 195.1, 158.7, 142.8, 141.3, 137.6, 137.4, 136.5, 135.85, 135.8 3, 133.6, 133.4, 133.2, 131.0, 129.2, 128.6, 128.0, 127.9, 127.74, $127.68,127.1,126.7,125.3,123.1,123.0,113.5,66.1,65.7,55.0,37.3,36.3$.

HRMS (ESI) for $\mathrm{C}_{38} \mathrm{H}_{29} \mathrm{NO}_{6} \mathrm{~S},[\mathrm{M}+\mathrm{Na}]^{+}(650.1608)$, found 650.1611 .

IR $(\mathrm{KBr}) \bar{v}\left(\mathrm{~cm}^{-1}\right): 3068,1739,1706,1511,1353,1249,1172,1086,720$.

$3 \mathbf{i}\left(99.1 \mathrm{mg}\right.$, yield 95\%, mp 204-205 $\left.{ }^{\circ} \mathrm{C}\right)$ : 1c (54.5 mg, $\left.0.2 \mathrm{mmol}\right)$ and 2a (46.9 mg, $0.2 \mathrm{mmol})$ as starting material, reacted for $3 \mathrm{~h}$.

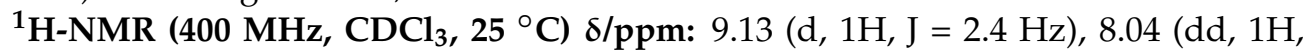
$\left.\mathrm{J}^{1}=8.0 \mathrm{~Hz}, \mathrm{~J}^{2}=0.8 \mathrm{~Hz}\right), 7.92(\mathrm{~d}, 1 \mathrm{H}, \mathrm{J}=7.6 \mathrm{~Hz}), 7.75\left(\mathrm{td}, 1 \mathrm{H}, \mathrm{J}^{1}=7.6 \mathrm{~Hz}, \mathrm{~J}^{2}=0.8 \mathrm{~Hz}\right)$, 7.73-7.68 (m, 2H), 7.67-7.61 (m, 2H), 7.57-7.51 (m, 3H), $7.41(\mathrm{~d}, 1 \mathrm{H}, \mathrm{J}=7.6 \mathrm{~Hz}), 7.30(\mathrm{td}, 1 \mathrm{H}$, $\left.\mathrm{J}^{1}=7.6 \mathrm{~Hz}, \mathrm{~J}^{2}=0.8 \mathrm{~Hz}\right), 7.04-6.96(\mathrm{~m}, 5 \mathrm{H}), 6.68(\mathrm{~d}, 1 \mathrm{H}, \mathrm{J}=7.8 \mathrm{~Hz}), 5.91(\mathrm{~s}, 1 \mathrm{H}), 2.61(\mathrm{dd}, 1 \mathrm{H}$, $\left.\mathrm{J}^{1}=11.8 \mathrm{~Hz}, \mathrm{~J}^{2}=2.4 \mathrm{~Hz}\right), 2.25\left(\mathrm{ddd}, 1 \mathrm{H}, \mathrm{J}^{1}=17.4 \mathrm{~Hz}, \mathrm{~J}^{2}=11.8 \mathrm{~Hz}, \mathrm{~J}^{3}=2.4 \mathrm{~Hz}\right), 1.83(\mathrm{dd}, 1 \mathrm{H}$, $\left.\mathrm{J}^{1}=17.4 \mathrm{~Hz}, \mathrm{~J}^{2}=2.4 \mathrm{~Hz}\right)$.

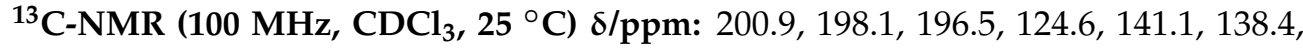
137.7, 137.4, 136.6, 136.0, 133.2, 133.0, 129.1, 128.4, 128.3, 128.2, 127.6, 127.3, 127.1, 126.7, $125.0,123.1,123.0,65.9,65.8,40.9,36.2$.

HRMS (ESI) for $\mathrm{C}_{31} \mathrm{H}_{23} \mathrm{NO}_{5} \mathrm{~S},[\mathrm{M}+\mathrm{Na}]^{+}$(544.1189), found 544.1194.

IR $(\mathrm{KBr}) \bar{v}\left(\mathrm{~cm}^{-1}\right): 3059,2861,1722,1710,1585,1357,1246,1169,1083,704$.

3j (125.9 mg, yield 93\%, mp 265-266 $\left.{ }^{\circ} \mathrm{C}\right)$ : 1c $(88.5 \mathrm{mg}, 0.2 \mathrm{mmol})$ and 2a $(46.9 \mathrm{mg}$, $0.2 \mathrm{mmol}$ ) as starting material, reacted for $3 \mathrm{~h}$.

${ }^{1} \mathrm{H}-\mathrm{NMR}\left(400 \mathrm{MHz}, \mathrm{CDCl}_{3}, 25{ }^{\circ} \mathrm{C}\right)$ //ppm: $8.03(\mathrm{~d}, 1 \mathrm{H}, \mathrm{J}=8.0 \mathrm{~Hz}), 7.91(\mathrm{~d}, 1 \mathrm{H}$, $\mathrm{J}=7.4 \mathrm{~Hz}), 7.74(\mathrm{t}, 1 \mathrm{H}, \mathrm{J}=7.6 \mathrm{~Hz}), 7.70-7.62(\mathrm{~m}, 3 \mathrm{H}),, 7.58-7.42(\mathrm{~m}, 9 \mathrm{H}), 7.21(\mathrm{t}, 1 \mathrm{H}$, $\mathrm{J}=7.6 \mathrm{~Hz}), 7.07-6.91(\mathrm{~m}, 5 \mathrm{H}), 6.68(\mathrm{~d}, 1 \mathrm{H}, \mathrm{J}=7.6 \mathrm{~Hz}), 5.84(\mathrm{~s}, 1 \mathrm{H}), 3.01(\mathrm{~d}, 1 \mathrm{H}, \mathrm{J}=11.2 \mathrm{~Hz})$, $2.87\left(\mathrm{dd}, 1 \mathrm{H}, \mathrm{J}^{1}=16.8 \mathrm{~Hz}, \mathrm{~J}^{2}=11.2 \mathrm{~Hz}\right), 2.31\left(\mathrm{dd}, 1 \mathrm{H}, \mathrm{J}^{1}=16.8 \mathrm{~Hz}, \mathrm{~J}^{2}=2.0 \mathrm{~Hz}\right)$.

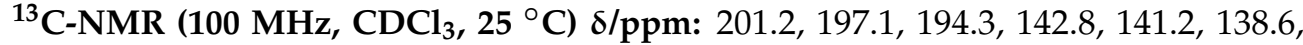
137.6, 137.3, 136.5, 135.9, 134.4, 133.3, 133.2, 132.0, 129.4, 129.1, 128.7, 128.1, 127.9, 127.8, $127.6,127.1,126.8,125.2,123.06,123.00,66.2,66.0,37.3,36.4$.

HRMS (ESI) for $\mathrm{C}_{37} \mathrm{H}_{26} \mathrm{BrNO}_{5} \mathrm{~S},[\mathrm{M}+\mathrm{H}]^{+}(676.0788)$, found 676.0783.

IR $(\mathrm{KBr}) \bar{v}\left(\mathrm{~cm}^{-1}\right): 3064,1741,1706,1585,1357,1250,1170,1071,757,582$.

3k (123.4 mg, yield 96\%, mp 269-270 $\left.{ }^{\circ} \mathrm{C}\right): 1 \mathrm{~d}(81.7 \mathrm{mg}, 0.2 \mathrm{mmol})$ and $2 \mathrm{a}(46.9 \mathrm{mg}$, $0.2 \mathrm{mmol}$ ) as starting material, reacted for $3 \mathrm{~h}$.

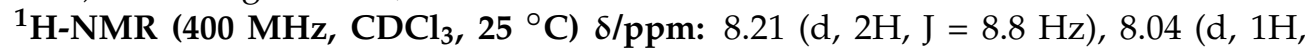
$\mathrm{J}=7.8 \mathrm{~Hz}), 7.93(\mathrm{~d}, 1 \mathrm{H}, \mathrm{J}=7.6 \mathrm{~Hz}), 7.83-7.74(\mathrm{~m}, 3 \mathrm{H}), 7.74-7.64(\mathrm{~m}, 3 \mathrm{H}), 7.61-7.43(\mathrm{~m}, 5 \mathrm{H})$, $7.22(\mathrm{t}, 1 \mathrm{H}, \mathrm{J}=7.4 \mathrm{~Hz}), 7.03-6.95(\mathrm{~m}, 5 \mathrm{H}), 6.60(\mathrm{~d}, 1 \mathrm{H}, \mathrm{J}=7.6 \mathrm{~Hz}), 5.84(\mathrm{~s}, 1 \mathrm{H}), 3.08-2.94(\mathrm{~m}$, 2H), $2.39(\mathrm{~d}, 1 \mathrm{H}, 15.6 \mathrm{~Hz})$. 
${ }^{13} \mathrm{C}-\mathrm{NMR}\left(100 \mathrm{MHz} \mathrm{CDCl}_{3}, 25{ }^{\circ} \mathrm{C}\right)$ 8/ppm: 201.2, 197.0, 193.8, 150.5, 142.8, 141.2, $140.1,138.5,137.8,137.4,136.7,136.0,133.2,133.0,129.2,129.0,128.2,128.10,127.98,127.7$, $127.2,126.82,126.79,124.9,123.9,123.2,123.1,66.3,66.0,37.1,36.9$.

HRMS (ESI) for $\mathrm{C}_{37} \mathrm{H}_{26} \mathrm{~N}_{2} \mathrm{O}_{7} \mathrm{~S},[\mathrm{M}+\mathrm{H}]^{+}(643.1533)$, found 643.1588 .

IR (KBr) $\bar{v}\left(\mathrm{~cm}^{-1}\right): 3429,3075,1706,1594,1524,1346,1251,1172,1089,735,558$.

31 (111.8 mg, yield 89\%, mp 219-220 $\left.{ }^{\circ} \mathrm{C}\right): \mathbf{1 e}(78.7 \mathrm{mg}, 0.2 \mathrm{mmol})$ and $\mathbf{2 a}(46.9 \mathrm{mg}$, $0.2 \mathrm{mmol})$ as starting material, reacted for $12 \mathrm{~h}$.

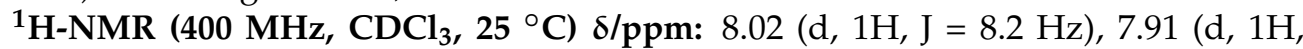
$\mathrm{J}=7.4 \mathrm{~Hz}), 7.75(\mathrm{t}, 1 \mathrm{H}, \mathrm{J}=7.4 \mathrm{~Hz}), 7.71(\mathrm{~d}, 2 \mathrm{H}, \mathrm{J}=7.8 \mathrm{~Hz}), 7.66(\mathrm{t}, 1 \mathrm{H}, \mathrm{J}=7.4 \mathrm{~Hz}), 7.61(\mathrm{~d}$, $2 \mathrm{H}, \mathrm{J}=8.8 \mathrm{~Hz}), 7.58-7.43(\mathrm{~m}, 5 \mathrm{H}), 7.20(\mathrm{t}, 1 \mathrm{H}, \mathrm{J}=7.6 \mathrm{~Hz}), 7.06-6.94(\mathrm{~m}, 5 \mathrm{H}), 6.83(\mathrm{~d}, 2 \mathrm{H}$, $\mathrm{J}=8.8 \mathrm{~Hz}), 6.70(\mathrm{~d}, 1 \mathrm{H}, \mathrm{J}=7.8 \mathrm{~Hz}), 5.86(\mathrm{~s}, 1 \mathrm{H}), 3.83(\mathrm{~s}, 3 \mathrm{H}), 3.05(\mathrm{~d}, 1 \mathrm{H}, \mathrm{J}=11.2 \mathrm{~Hz}), 2.88$ $\left(\mathrm{dd}, 1 \mathrm{H}, \mathrm{J}^{1}=16.6 \mathrm{~Hz}, \mathrm{~J}^{2}=11.2 \mathrm{~Hz}\right), 2.29\left(\mathrm{dd}, 1 \mathrm{H}, \mathrm{J}^{1}=16.6 \mathrm{~Hz}, \mathrm{~J}^{2}=2.0 \mathrm{~Hz}\right)$.

${ }^{13} \mathrm{C}-\mathrm{NMR}\left(100 \mathrm{MHz} \mathrm{CDCl}_{3}, 2{ }^{\circ} \mathrm{C}\right)$ )/ppm: 201.3, 197.3, 193.6, 163.7, 142.7141.3, $138.8,137.6,137.3,136.4,135.8,133.7,133.2,130.2,129.2,128.9,128.1,127.8,127.7,127.5$, $127.1,126.8,125.4,123.0,123.1,113.8,66.1,66.0,55.5,37.5,36.0$.

HRMS (ESI) for $\mathrm{C}_{38} \mathrm{H}_{29} \mathrm{NO}_{6} \mathrm{~S},[\mathrm{M}+\mathrm{H}]^{+}(628.1788)$, found 628.1800.

IR $(\mathrm{KBr}) \bar{v}\left(\mathrm{~cm}^{-1}\right):$ 3430, 3066, 1706, 1685, 1599, 1354, 1251, 1169, 735, 582.

$3 \mathrm{~m}\left(110.2 \mathrm{mg}\right.$, yield 85\%, mp 250-251 $\left.{ }^{\circ} \mathrm{C}\right): \mathbf{1 g}(82.7 \mathrm{mg}, 0.2 \mathrm{mmol})$ and $\mathbf{2 a}(46.9 \mathrm{mg}$, $0.2 \mathrm{mmol}$ ) as starting material, reacted for $6 \mathrm{~h}$.

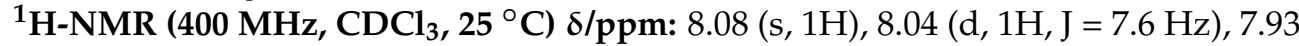
$(\mathrm{d}, 1 \mathrm{H}, \mathrm{J}=7.6 \mathrm{~Hz}), 7.89(\mathrm{~d}, 1 \mathrm{H}, \mathrm{J}=7.8 \mathrm{~Hz}), 7.81\left(\mathrm{dd}, 2 \mathrm{H}, \mathrm{J}^{1}=12.0 \mathrm{~Hz}, \mathrm{~J}^{2}=8.2 \mathrm{~Hz}\right), 7.76-7.67$ $(\mathrm{m}, 2 \mathrm{H}), 7.64-7.50(\mathrm{~m}, 5 \mathrm{H}), 7.50-7.43(\mathrm{~m}, 2 \mathrm{H}), 7.28-7.19(\mathrm{~m}, 3 \mathrm{H}), 7.14(\mathrm{t}, 1 \mathrm{H}, \mathrm{J}=7.4 \mathrm{~Hz}), 7.06$ $(\mathrm{d}, 1 \mathrm{H}, \mathrm{J}=6.6 \mathrm{~Hz}), 7.02-6.89(\mathrm{~m}, 4 \mathrm{H}), 5.89(\mathrm{~s}, 1 \mathrm{H}), 3.10(\mathrm{~d}, 1 \mathrm{H}, \mathrm{J}=11.2 \mathrm{~Hz}), 3.01(\mathrm{dd}, 1 \mathrm{H}$, $\left.\mathrm{J}^{1}=15.6 \mathrm{~Hz}, \mathrm{~J}^{2}=11.2 \mathrm{~Hz}\right), 2.54\left(\mathrm{dd}, 1 \mathrm{H}, \mathrm{J}^{1}=15.6 \mathrm{~Hz}, \mathrm{~J}^{2}=2.0 \mathrm{~Hz}\right)$.

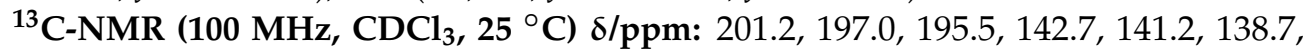
$137.4,137.2$, 136.5, 135.9, 135.5, 133.5, 132.9, 132.8, 132.2, 129.7, 129.5, 128.9, 128.7, 128.5, $128.0,127.8,127.6,127.5,126.81,126.77,126.67,125.4,123.5,122.9,66.1,66.0,37.8,36.6$.

HRMS (ESI) for $\mathrm{C}_{41} \mathrm{H}_{29} \mathrm{NO}_{5} \mathrm{~S},[\mathrm{M}+\mathrm{H}]^{+}(648.1839)$, found 648.1846. $733,582$.

IR $(\mathrm{KBr}) \bar{v}\left(\mathrm{~cm}^{-1}\right): 3430,3063,1741,1706,1682,1593,1356,1251,1170,1091,755$,

\subsection{Cell Culture}

$\mathrm{HaCaT}$ cells which were kindly provided by Prof. Hung-Rong Yen (Integration of Traditional Chinese-Western Medicine Research Institute, China Medical University Hospital, Taiwan) were maintained in a high-glucose Dulbecco's modified Eagle medium (DMEM), which was supplemented with $10 \%$ fetal bovine serum (FBS) and 1\% penicillin and streptomycin. Cells were cultured at $37^{\circ} \mathrm{C}$ in a humidified environment of $5 \% \mathrm{CO}_{2}$. Then, $0.25 \%$ Trypsin-EDTA was used to vaccinate when the amount of cultured cells reached $1 \times 10^{6}[32]$.

\subsection{Cell Viability Assay}

Cytotoxicity was analyzed using the MTT assay, with slight modifications. Briefly, HaCaT cells were seeded in 96-well plates to allow for overnight adhesion. The following day, cells were treated with various concentrations $(0,6.25,12.5,25,50$, and $100 \mu \mathrm{M})$ of each compound for $24 \mathrm{~h}$. After treatment, MTT $(100 \mu \mathrm{L} / \mathrm{mL})$ was added to each well and incubated for $1 \mathrm{~h}$ at $37^{\circ} \mathrm{C}$ under $5 \% \mathrm{CO}_{2}$, and then DMSO $(100 \mu \mathrm{L})$ was added to dissolve the formazan in the cells. The absorbance at $575 \mathrm{~nm}$ was measured using a microplate spectrophotometer. The results are expressed as a percentage of the corresponding controls [33].

\subsection{Scratch Assay}

$\mathrm{HaCaT}$ cells using a culture-insert ( $\mu$-Dish35mm, high, BLOSSOM BIOTECHNOLOGIES INC, Taipei, Taiwan) seeded in the precoated 24-well plates each compartment of the insert filled with $100 \mu \mathrm{L}$ of cell suspension (about $2 \times 10^{5}$ cells / chamber) for $24 \mathrm{~h}$ at $37{ }^{\circ} \mathrm{C}$ and $5 \% \mathrm{CO}_{2}$. The cell debris was removed by washing with PBS when the cells 
grow to $80 \%$ confluence. Serum medium (control) and medium containing each tested compound $(6.25,12.5,25,50$, and $100 \mu \mathrm{M})$ were added to corresponding wells, and the cells were cultured with serum supplemented DMEM for $36 \mathrm{~h}$ at $37^{\circ} \mathrm{C}$ with $5 \% \mathrm{CO}_{2}[34,35]$. All scratch assays were conducted in triplicate. The areas of cell migration were analyzed using ImageJ software.

The wound closures were evaluated using the following formula:

$$
\text { Wound closure }(\%)=100-[(\text { sample area/control area }) \times 100] \text {. }
$$

\subsection{Splints}

The outer diameter, inner diameter, and thickness of round silicone splints were 26 , 16 , and 500-600 mm, respectively. All procedures and instruments were conducted and prepared, respectively, under aseptic conditions, which were maintained using autoclaves, ethylene oxide gas, $70 \%$ ethanol, and povidone-iodine. Mice were anesthetized with pentobarbital. An electric razor was used to remove the back hair, and a circular mark $(1.0 \mathrm{~cm}$ diameter) was placed on the center of the lumbar area; this section of skin was totally excised using scissors. A splint was inserted beneath the skin near the wound defect and attached to the fascia with 6-stitch ligations. The splint was then fixed to the skin with surgical silk thread (6 stitches at regular intervals) [36,37].

\subsection{Preparation of Sample-Containing PEG-Based Ointment}

PEG $400 \mathrm{Da}(100 \mathrm{mg})$ and PEG $4 \mathrm{kDa}(20 \mathrm{mg})$ were mixed at a ratio of 5:1. The mixture was then heated to above $85^{\circ} \mathrm{C}$ until it became a clear solution. The prepared compound $(1 \mathrm{mg})$ was added to the solution before the solution was allowed to cool to room temperature, forming a gel [38].

\subsection{Animal Experiments}

Compounds were tested in 8-week-old wild-type male C57BL/ 6 mice (BioLASCO Taiwan Co., Ltd., Taipei, Taiwan). The mice were artificially wounded using splints. The control gel or the compound-containing gel was applied daily and photographed to measure the wound area for 13 days. The mice were sacrificed by $\mathrm{CO}_{2}$ exposure, and the tissues at the location of the silicone ring were removed for subsequent analysis.

\subsection{Statistical Analysis}

Analyses were performed in triplicate, and the results were expressed as mean $\pm \mathrm{SD}$. Analysis of variance (ANOVA) was conducted, followed by Dunnett's post hoc test, to determine significant $(p<0.05)$ differences. Statistical analyses were performed using GraphPad Prism v8.0 (GraphPad Software, San Diego, CA, USA).

\section{Conclusions}

In this article, we developed a one-pot reaction method that requires only a small amount of catalyst to obtain nonselective isomers with high selectivity. In addition, the experimental procedure is simple and only requires extraction and recrystallization. The reaction was performed at room temperature and had a good yield. This reaction will be studied in our further research by using different catalysts. We hope that the synthesis strategy described in this article can be widely applied to various starting materials with diverse substituents. We also hope that the synthesis of spiro-tetrahydroqunioline derivatives could provide a new method for identifying chemicals that can be applied to wound-healing research. Further structural modifications and biological evaluations are ongoing, and the results will be reported in due course.

Supplementary Materials: Supplementary materials can be found at https:/ / www.mdpi.com/ article/10.3390/ijms22126251/s1. 
Author Contributions: Methodology, conceptualization and design of study Y.-C.L. and Y.-A.L. writing-original draft preparation, K.W.; data curation, W.L. and J.-C.Y.; writing-review and editing, Y.-J.J. and K.W.; project administration and funding acquisition, W.L., Y.-C.W., J.-C.Y. and Y.-J.J. All authors have read and agreed to the published version of the manuscript.

Funding: This work is supported by the Ministry of Science and Technology, Taiwan (MOST 1072628-M-003-001-MY3, MOST 109-2320-B-039-063-, MOST 107-2320-B-039-017-MY3, and MOST 1082113-M-039-005-) and China Medical University, Taiwan (CMU108-MF-96) for financial support.

Institutional Review Board Statement: The Institutional Animal Care (IACUC) of China Medical University has approved this specific protocols used in this study (approval number: CMUIACUC2018-221; date: 19 January 2018).

Data Availability Statement: Not applicable.

Conflicts of Interest: The authors declare no conflict of interest.

$\begin{array}{ll}\text { Abbreviations } \\ \text { TLC } & \text { thin layer chromatography } \\ \text { NMR } & \text { nuclear magnetic resonance } \\ \text { DABCO } & \text { 1:4-diazabicyclo[2.2.2]octane } \\ \text { DMAP } & \text { 4-dimethylaminopyridine } \\ \text { Et3N } & \text { triethylamine } \\ \text { DCM } & \text { dichloromethane } \\ \text { Et2O } & \text { ether } \\ \text { THF } & \text { tetrahydrofuran } \\ \text { EA } & \text { ethyl acetate } \\ \text { MeCN } & \text { acetonitrile } \\ \text { r.t. } & \text { room temperature } \\ \text { Mp } & \text { melting point } \\ \text { FBS } & \text { fetal bovine serum } \\ \text { MTT } & \text { methythiazolyltetrazolium } \\ \text { PEG } & \text { polyethylene glycol }\end{array}$

\section{References}

1. Schulz, J.T., III; Tompkins, R.G.; Burke, J.F. Artificial Skin. Annu. Rev. Med. 2000, 51, 231. [CrossRef]

2. Sun, G.; Mao, J.J. Engineering dextran-based scaffolds for drug delivery and tissue repair. Nanomedicine 2012, 1771-1784. [CrossRef] [PubMed]

3. Sabine, W.; Richard, G. Regulation of wound healing by growth factors and cytokines. Physiol. Rev. 2003, 83, 835-870.

4. Eming, S.A.; Martin, P.; Tomic-Canic, M. Wound repair and regeneration: Mechanisms, signaling, and translation. Sci. Transl. Med. 2014, 6, 265. [CrossRef] [PubMed]

5. Sorg, H.; Tilkorn, D.J.; Hager, S.; Hauser, J.; Mirastschijski, U. Skin Wound Healing: An Update on the Current Knowledge and Concepts. Eur. Surg. Res. 2017, 58, 81-94. [CrossRef]

6. Sosne, G.; Qiu, P.; Goldstein, A.L.; Wheater, M. Biological activities of thymosin beta4 defined by active sites in short peptide sequences. FASEB J. 2010, 24, 2144-2151. [CrossRef]

7. Li, X.; Wang, Y.; Zou, Z.; Yang, M.; Wu, C.; Su, Y.; Tang, J.; Yang, X. OM-LV20, a novel peptide from odorous frog skin, accelerates wound healing in vitro and in vivo. Chem. Biol. Drug Des. 2018, 91, 126-136. [CrossRef] [PubMed]

8. Arturson, G. Pathophysiology of the burn wound and pharmacological treatment. The Rudi Hermans Lecture, 1995. Burns 1996, 22, 255. [CrossRef]

9. Kumar, S.; Bawa, S.; Gupta, H. Biological activities of quinoline derivatives. Mini-Rev. Med. Chem. 2009, 9, 1648-1654. [CrossRef]

10. Kubica, K.; Taciak, P.; Czajkowska, A.; Ignasiak, A.S.; Wyrebiak, R.; Podsadni, P.; Bia£y, I.M.; Malejczyk, J.; Mazurek, A.P. Synthesis and anticancer activity evaluation of some new derivatives of 2-(4-benzoyl-1-piperazinyl)-quinoline and 2-(4-cinnamoyl1-piperazinyl)-quinoline. Acta Pol. Pharm. Drug Res. 2018, 75, 891-901. [CrossRef]

11. Li, W.; Shuai, W.; Sun, H.; Xu, F.; Bi, Y.; Xu, J.; Ma, C.; Yao, H.; Zhu, Z.; Xu, S. Design, synthesis and biological evaluation of quinoline-indole derivatives as anti-tubulin agents targeting the colchicine binding site. Eur. J. Med. Chem. 2019, 163, 428-442. [CrossRef] [PubMed]

12. Prakash Naik, H. Bhojya Naik, H.; Ravikumar Naik, T.; Naika, H.; Gouthamchandra, K.; Mahmood, R.; Khadeer Ahamed, B. Synthesis of novel benzo[h]quinolines: Wound healing, antibacterial, DNA binding and in vitro antioxidant activity. Eur. J. Med. Chem. 2009, 44, 981-989. [CrossRef] [PubMed] 
13. Hua, J.; Teng, P.; Zou, Y.; Zhang, C.; Shen, X.; Cai, J.; Hu, Y. Small antimicrobial agents encapsulated in poly(epsilon-caprolactone)poly(ethylene glycol) nanoparitcles for treatment of S. aureus-infected wounds. J. Nanopart. Res. 2018, 20, 270. [CrossRef]

14. Goli, N.; Mainkar, P.; Kotapalli, S.; Tejaswini, K.; Ummanni, R.; Chandrasekhar, S. Expanding the tetrahydroquinoline pharmacophore. Bioorg. Med. Chem. Lett. 2017, 8, 1714-1720. [CrossRef] [PubMed]

15. Mail kumaran, P.; Sheeja Devi, K.; Manikantha mouli, C.H.; Manjula, M.; Smylin Ajitha Rani, S.; Krishnamalar, G. Synthesis, characterization and wound healing activity of tetrazoloquinoline thiocarbohydrazide derivatives. Int. J. Res. Pharm. Nano Sci. 2012, 1, 70-79.

16. Duan, J.D.; Cheng, J.; Li, P.F. Enantioselective Construction of Spiro-1,3-indandiones with Three Stereocenters via Organocatalytic Michael-Aldol Reaction of 2-Arylideneindane-1,3-diones and Nitro Aldehydes. Org. Chem. Front. 2015, 2, 1048-1052. [CrossRef]

17. Singh, G.S. and Desta, Z.Y. Isatins as privileged molecules in design and synthesis of spiro-fused cyclic frameworks. Chem. Rev. 2012, 112, 6104. [CrossRef]

18. Chai, Z.; Rainey, T.J. Pd(II)/brønsted acid catalyzed enantioselective allylic C-H activation for the synthesis of spiro-cyclic rings. J. Am. Chem. Soc. 2012, 134, 3615. [CrossRef]

19. Pandey, R.C.; Toussaint, M.W.; Stroshane, R.M.; Kahta, C.C.; Aszalos, A.A.; Garretson, A.L.; Wei, T.T.; Byrne, K.M.; Geoghegan, R.F., Jr.; White, R.J.I. Fredericamycin A, a new antitumor antibiotic. I. Production, isolation and physicochemical properties. Antibiotics 1981, 34, 1389. [CrossRef]

20. Clive, D.L.J.; Kong, X.L.; Paul, C.C. Further Model Studies Related to Fredericamycin A: Analogues in which Ring C is Expanded to Six Atoms, and an Examination of the Diastereoselectivity of Radical Spiro-cyclization. Tetrahedron 1996, 52, 6085-6116. [CrossRef]

21. Evans, P.A.; Brandt, T.A. Palladium Catalyzed Cross-Coupling Acylation Approach to the Antitumor Antibiotic Fredericamycin A. Tetrahedron Lett. 1996, 37, 1367-1370. [CrossRef]

22. Pizzirani, D.; Roberti, M.; Grimaudo, S.; Cristina, A.; Pipitone, R.M.; Tolomeo, M.; Recanatini, M. Identification of Biphenyl-Based Hybrid Molecules Able To Decrease the Intracellular Level of Bcl-2 Protein in Bcl-2 Overexpressing Leukemia Cells. J. Med. Chem. 2009, 52, 6936-6940. [CrossRef] [PubMed]

23. Ren, Z.; Cao, W.; Tong, W.; Chen, J.; Deng, H.; Wu, D. Triphenylarsine-catalyzed cyclopropanation: Highly stereoselective synthesis of trans -2,3-dihydro-spiro[cyclopropane-1, $2^{\prime}$-indan- $1^{\prime}, 3^{\prime}$-dione] from alkene and phenacyl bromide. Synth. Commun. 2008, 38, 2200. [CrossRef]

24. Russo, A.; Meninno, S.; Tedesco, C.; Lattanzi, A. Synthesis of Activated Cyclopropanes by an MIRC Strategy: An Enantioselective Organocatalytic Approach to Spiro-cyclopropanes. Eur. J. Org. Chem. 2011, 5096. [CrossRef]

25. Lu, Y.L.; Sun, J.; Jiang, Y.H.; Yan, C.G. Diastereoselective synthesis of spiro [indene-2,20-pyrazolo [1,2-a] pyrazoles] and spiro [indoline-3,20-pyrazolo [1,2-a] pyrazoles] via 1,3-dipolar cycloaddition. RSC Adv. 2016, 6, 50471-50478. [CrossRef]

26. Mahajan, S.; Chauhan, P.; Blümel, M.; Puttreddy, R.; Rissanen, K.; Raabe, G.; Enders, D. Asymmetric Synthesis of Spiro Tetrahydrothiophene-indan-1,3-diones via a Squaramide-Catalyzed Sulfa-Michael/Aldol Domino Reaction. Synthesis 2016, 48, 41131-41138. [CrossRef]

27. Das, U.; Tsai, Y.L.; Lin, W. An efficient organocatalytic enantioselective synthesis of spiro-nitrocyclopropanes. Org. Biomol. Chem. 2013, 11, 44-47. [CrossRef]

28. Madhusudhan Reddy, G.; Ko, C.T.; Hsieh, K.H.; Lee, C.J.; Das, U.; Lin, W. Expanding the Scope of Primary Amine Catalysis: Stereoselective Synthesis of Indanedione-Fused 2,6-Disubstituted trans-spiro-cyclohexanones. J. Org. Chem. 2016, 81, $2420-2431$. [CrossRef]

29. Lin, Y.; Chu, P.; Ma, W.; Cheng, W.; Chan, S.; Yang, J.; Wu, Y. Enzyme-digested peptides derived from Lates calcarifer enhance wound healing after surgical repair. Mar. Drug 2021, 19, 154. [CrossRef]

30. Song, Y.X.; Du, D.M. Asymmetric synthesis of highly functionalized spirothiazolidinone tetrahydroquinolines via a squaramidecatalyzed cascade reaction. Org. Biomol. Chem. 2018, 16, 9390-9401. [CrossRef]

31. X-ray Crystallographic Data of Compound CCDC 1863526. Available online: www.ccdc.cam.ac.uk/data_request/cif (accessed on 1 May 2021).

32. Liu, S.P.; Shibu, M.A.; Tsai, F.J.; Hsu, Y.M.; Tsai, C.H.; Chung, J.G.; Yang, J.S.; Tang, C.H.; Wang, S.; Li, Q.; et al. Tetramethylpyrazine reverses high-glucose induced hypoxic effects by negatively regulating HIF-1alpha induced BNIP3 expression to ameliorate H9c2 cardiomyoblast apoptosis. Nutr. Metab. 2020, 17, 12. [CrossRef] [PubMed]

33. Lee, H.P.; Wang, S.W.; Wu, Y.C.; Tsai, C.H.; Tsai, F.J.; Chung, J.G.; Huang, C.Y.; Yang, J.S.; Hsu, Y.M.; Yin, M.C.; et al. Glucocerebroside reduces endothelial progenitor cell-induced angiogenesis. Food Agric. Immunol. 2019, 30, 1033-1045. [CrossRef]

34. Koo, Y.M.; Yun, Y.H. Effects of polydeoxyribonucleotides (PDRN) on wound healing: Electric cell-substrate impedance sensing (ECIS). Mater. Sci. Eng. C Mater. Biol. Appl. 2016, 554-560. [CrossRef] [PubMed]

35. Lin, C.C.; Chen, K.B.; Tsai, C.H.; Tsai, F.J; Huang, C.Y.; Tang, C.H.; Yang, J.S.; Hsu, Y.M.; Peng, S.F.; Chung, J.-G. Casticin inhibits human prostate cancer DU 145 cell migration and invasion via Ras/Akt/NF-kB signaling pathways. J. Food Biochem. 2019, 43, e12902. [CrossRef]

36. Jimi, S.; Francesco, D.F.; Ferraro, G.; Riccio, M.; Hara, S. A Novel Skin Splint for Accurately Mapping Dermal Remodeling and Epithelialization during Wound Healing. J. Cell Physiol. 2016, 232, 1225-1232. [CrossRef] 
37. Marshall, C.D.; Hu, M.S.; Leavitt, T.; Barnes, L.A.; Cheung, A.T.; Malhotra, S.; Lorenz, H.P.; Delp, S.L.; Quake, S.R.; Longaker, M.T. Sanativo Wound Healing Product Does Not Accelerate Reepithelialization in a Mouse Cutaneous Wound Healing Model. Plast. Reconstr. Surg. 2017, 139, 343-352. [CrossRef]

38. Kang, Y.K.; Lee, Y.M.; Im, S.; Park, H.; Kim, W.J. Nitric oxide-releasing polymer incorporated ointment for cutaneous wound healing. J. Control. Release 2015, 220, 624-630. [CrossRef] 